Article

\title{
The Promoting Effect of Ni on Glycerol Hydrogenolysis to 1,2-Propanediol with In Situ Hydrogen from Methanol Steam Reforming Using a $\mathrm{Cu} / \mathrm{ZnO} / \mathrm{Al}_{2} \mathrm{O}_{3}$ Catalyst
}

\author{
Yuanqing Liu ${ }^{1} \mathbb{D}$, Xiaoming Guo ${ }^{2}$, Garry L. Rempel ${ }^{1,+}$ and Flora T. T. $\operatorname{Ng}^{1, *}$ \\ 1 Department of Chemical Engineering, University of Waterloo, 200 University Ave. W., \\ Waterloo, ON N2L3G1, Canada; y289liu@uwaterloo.ca \\ 2 Research Institute of Applied Catalysis, School of Chemical and Environmental Engineering, \\ Shanghai Institute of Technology, Shanghai 201418, China; guoxiaoming@sit.edu.cn \\ * Correspondence: fttng@uwaterloo.ca; Tel.: +1-519-888-4567 (ext. 33979) \\ + Deceased November 2, 2018, this paper is dedicated to the memory of Professor Garry L. Rempel.
}

Received: 26 February 2019; Accepted: 18 April 2019; Published: 1 May 2019

\begin{abstract}
Production of green chemicals using a biomass derived feedstock is of current interest. Among the processes, the hydrogenolysis of glycerol to 1,2-propanediol (1,2-PD) using externally supplied molecular hydrogen has been studied quite extensively. The utilization of methanol present in crude glycerol from biodiesel production can avoid the additional cost for molecular hydrogen storage and transportation, as well as reduce the safety risks due to the high hydrogen pressure operation. Recently the hydrogenolysis of glycerol with a $\mathrm{Cu} / \mathrm{ZnO} / \mathrm{Al}_{2} \mathrm{O}_{3}$ catalyst using in situ hydrogen generated from methanol steam reforming in a liquid phase reaction has been reported. This paper focusses on the effect of added $\mathrm{Ni}$ on the activity of a $\mathrm{Cu} / \mathrm{ZnO} / \mathrm{Al}_{2} \mathrm{O}_{3}$ catalyst prepared by an oxalate gel-co-precipitation method for the hydrogenolysis of glycerol using methanol as a hydrogen source. It is found that Ni reduces the conversion of glycerol but improves the selectivity to 1,2-PD, while a higher conversion of methanol is observed. The promoting effect of $\mathrm{Ni}$ on the selectivity to 1,2-PD is attributed to the slower dehydration of glycerol to acetol coupled with a higher availability of in situ hydrogen produced from methanol steam reforming and the higher hydrogenation activity of $\mathrm{Ni}$ towards the intermediate acetol to produce 1,2-PD.
\end{abstract}

Keywords: glycerol hydrogenolysis; in situ hydrogen; methanol steam reforming; $\mathrm{Ni} / \mathrm{Cu} / \mathrm{ZnO} / \mathrm{Al}_{2} \mathrm{O}_{3}$ catalysts

\section{Introduction}

Fossil based fuels such as diesel, gasoline and jetfuel have been the most important energy resources affecting human life and modern society in the past century. However, fossil fuel is a non-renewable resource and energy demand has rapidly increased. Currently many researchers are working on alternative sources of renewable energy to reduce the dependence on fossil fuel, especially in view of the emission of greenhouse gases and climate change. Biodiesel has been used to supplement fossil diesel [1] and has already been commercialized in the world. Glycerol, the major by-product from the biodiesel production process, can be utilized to produce a number of value added chemicals such as 1,2-propanediol, 1,3-propanediol, acrolein, acrylic acid and some other special chemicals. Approximately $1 \mathrm{~kg}$ of glycerol can be formed for every $9 \mathrm{~kg}$ of biodiesel produced via a transesterification reaction using vegetable oil or animal fat as the feedstocks. Adding value to glycerol will not only lower the production cost of biodiesel but also avoid the chemical waste and environmental 
hazards caused by the large amount of surplus crude glycerol [2,3]. Among all of these applications, the production of 1,2-propanediol (1,2-PD), also known as propylene glycol, has been extensively researched because high 1,2-PD selectivity can be obtained under relatively mild reaction conditions compared with other routes of glycerol upgrading [4-7]. Xia et al. in 2012 reported a $\mathrm{Cu} / \mathrm{Zn} / \mathrm{Mg} / \mathrm{Al}$ mixed oxide catalyst where 1,2-PD selectivity can reach $99.7 \%$ under very mild reaction conditions with molecular hydrogen [8]. It has been most frequently reported that 1,2-PD is produced via a glycerol dehydration to form acetol followed by a hydrogenation of acetol $[5,6,9]$. The conventional glycerol hydrogenolysis reaction is carried out in a batch reactor with heterogeneous catalysts under hydrogen pressure up to $10 \mathrm{MPa}[10,11]$. However, the high hydrogen pressure will incur a significant cost issue related to molecular hydrogen transportation and storage [12]. Additionally, the high pressure hydrogen in the storage tanks and reactors can cause safety problems due to the potential leak and explosion on contact with air.

To overcome the drawbacks of using high pressure molecular hydrogen, the process without adding external hydrogen has received a lot of interest from researchers. The most frequently reported approach is that the in situ hydrogen is produced via liquid phase glycerol steam reforming (known as APR-aqueous phase reforming) in a batch reactor and used for the glycerol hydrogenolysis process. $\mathrm{D}^{\prime}$ Hondt et al. was the first group who reported this process in 2008 using a Pt/NaY catalyst to convert glycerol to 1,2-PD in the absence of added hydrogen [13]. Under inert atmosphere using $20 \mathrm{wt} \%$ aqueous glycerol at $230^{\circ} \mathrm{C}$, after $15 \mathrm{~h}$ reaction time, the glycerol conversion was reported to be $85.4 \%$ with $64 \% 1,2-\mathrm{PD}$ selectivity. The advantage of this process is that glycerol itself is the raw material for both hydrogen and 1,2-PD production, no other hydrogen donor is needed avoiding the additional downstream separation steps. However, in order to get sufficient hydrogen from the glycerol reforming process at relatively low temperature $\left(\leq 250^{\circ} \mathrm{C}\right)$, a Pt based catalyst is usually used [14,15]. Pt is an expensive metal resulting in a high production cost for this process. Barbelli et al. in 2012 investigated a supported Pt catalyst with a lower Pt loading $(1 \mathrm{wt} \%)$ as well as the promoting effect of Sn for the APR process [16]. The experimental results showed that using monometallic $1 \mathrm{wt} \% \mathrm{Pt}$ on $\mathrm{SiO}_{2}$ catalyst and $10 \mathrm{wt} \%$ aqueous glycerol feedstock, at $200{ }^{\circ} \mathrm{C}$ after $2 \mathrm{~h}$ reaction, the glycerol conversion is only $1 \%$; when $0.4 \mathrm{wt} \% \mathrm{Sn}$ was added, the glycerol conversion and 1,2-PD selectivity were improved to 49\% and 63\% respectively. Roy et al. in 2010 [17] and Pendem et al. in 2012 [18] also reported the hydrogenolysis of glycerol using various Pt based catalysts, the 1,2-PD selectivities were all quite low compared with the process using externally supplied hydrogen.

The other route of the glycerol hydrogenolysis process without external hydrogen added is to use a hydrogen donor such as iso-propanol. Musolino et al. reported a glycerol hydrogenolysis process under an inert atmosphere using $10 \mathrm{wt} \% \mathrm{Pd}$ supported on $\mathrm{Fe}_{2} \mathrm{O}_{3}[19,20]$. Using glycerol iso-propanol solution ( $12 \mathrm{wt} \%$ with respect to glycerol) as feedstock, at $180^{\circ} \mathrm{C}$ for $24 \mathrm{~h}$, the glycerol conversion and 1,2-PD selectivity were reported to be $100 \%$ and $94 \%$ respectively. Gandarias et al. in 2011 reported a process with iso-propanol as a hydrogen donor using a $\mathrm{Ni}-\mathrm{Cu} / \mathrm{Al}_{2} \mathrm{O}_{3}$ catalyst prepared by a so-gel method [21] which is relatively cheaper than a Pd based catalyst as mentioned previously. Using a $4 \mathrm{wt} \%$ glycerol solution as the feedstock and an equal molar of isopropanol with respect to glycerol as hydrogen donor, at $220^{\circ} \mathrm{C}$, after $24 \mathrm{~h}$ reaction time, the glycerol conversion was $41.2 \%$ and the selectivity of 1,2-PD was only $48.3 \%$. Another active hydrogen donor for this process is formic acid, which can be obtained from non-food biomass sources. Gandarias et al. in 2012 developed a semi-batch system using a $\mathrm{Ni}-\mathrm{Cu} / \mathrm{Al}_{2} \mathrm{O}_{3}$ catalyst with the hydrogen donor being pumped into the reactor continuously [22]. Three different hydrogen donors were investigated, i.e., methanol, iso-propanol and formic acid. The glycerol conversion and 1,2-propanediol selectivity using formic acid were the highest among those three sources which were $33.5 \%$ and $85.9 \%$ respectively at $220{ }^{\circ} \mathrm{C}$ after $10 \mathrm{~h}$ reaction time. Recently, Gandarias et al. modified the catalyst and optimized the reaction conditions and developed a kinetic model for this process [23,24]. The optimum glycerol conversion and 1,2-PD selectivity were $55.2 \%$ and $84.6 \%$ respectively. The advantage of adding another hydrogen donor is that hydrogen can be produced under milder conditions compared with glycerol aqueous 
phase reforming resulting in a higher 1,2-PD selectivity. However, other downstream separation steps are needed to separate the impurities, such as acetone, unreacted formic acid and iso-propanol, causing a higher production cost.

We have been working on the upgrading of glycerol using in situ hydrogen generated from steam reforming of methanol $[25,26]$. Methanol has the highest $\mathrm{H} / \mathrm{C}$ ratio $(4: 1)$ compared with formic acid or iso-propanol and is widely used for transesterification reaction for biodiesel production. Stoichiometrically, one mole of triglyceride requires three moles of methanol to produce three moles of methyl ester and one mole of glycerol. An excess amount of methanol is usually added to drive the transesterification reaction towards methyl ester, the ratio of methanol to triglyceride usually ranges from 6:1 to 12:1. In a conventional biodiesel production plant, the unreacted methanol is recovered before sending the crude biodiesel and crude glycerol mixture into a decanter for separation [27]. It has been studied that methanol can be more preferably dissolved in glycerol phase suggested by very small distribution coefficients of methanol in biodiesel to glycerol being less than 0.2 [28]. Therefore, if the crude glycerol is separated from the crude biodiesel before a methanol recovery process, a large amount of un-reacted methanol will be presented in the crude glycerol phase. The amount of methanol present in the crude glycerol before methanol recovery was estimated to range from $29 \%$ to $62 \%$ depending on the methanol to oil feed molar ratio. The real industrial data provided by Shandong Dingyu Bio-energy Co. Ltd. (Laiwu, China), which is one of the largest biodiesel manufacturing plants in China, using refined palm stearin oil as the feedstock meets a good agreement with our estimation (see the Supplementary Document A1). The excess methanol present in glycerol can be utilized to provide hydrogen in situ for glycerol hydrogenolysis, and the methanol stored in the biodiesel plant can always ensure that the desired methanol content in crude glycerol can be obtained. Biodiesel plants normally do not have $\mathrm{H}_{2}$ plants on site, utilization of the methanol for hydrogen production on site could increase the overall economics for the production of 1,2-PD.

It is interesting to note that professor Lemonidou's group has recently published a few papers on glycerol hydrogenolysis to produce 1,2-PD using in situ hydrogen produced from methanol steam reforming [29-33]. Their initial work compared the activities of $\mathrm{Cu} / \mathrm{ZnO} / \mathrm{Al}_{2} \mathrm{O}_{3}$ and $\mathrm{Pt} / \mathrm{SiO}_{2}$ catalysts [29]. Under the conditions of $3.5 \mathrm{MPa} \mathrm{N}_{2}, 250{ }^{\circ} \mathrm{C}, 7.2 \mathrm{wt} \%$ methanol, $11.4 \mathrm{wt} \%$ glycerol, the glycerol conversion and 1,2-PD selectivity using a $\mathrm{Cu} / \mathrm{ZnO} / \mathrm{Al}_{2} \mathrm{O}_{3}$ catalyst prepared via oxalate gel-co-precipitation method $(88.8 \%$ and $39.2 \%$ respectively) were significantly higher than that using a $\mathrm{Pt} / \mathrm{SiO}_{2}$ catalyst $(58.9 \%$ and $36.2 \%$ respectively). By comparison, using a $\mathrm{Cu}$ based catalyst, the selectivities of propanol and ethylene glycol were significantly lower than those using a $\mathrm{Pt} / \mathrm{SiO}_{2}$ catalyst revealing that the $\mathrm{Cu} / \mathrm{ZnO} / \mathrm{Al}_{2} \mathrm{O}_{3}$ catalyst has less promotion effect on the $\mathrm{C}-\mathrm{C}$ cleavage reaction and sequential 1,2-PD hydrogenolysis. It is generally accepted that the dehydration of glycerol to acetol is the rate determining step in the hydrogenolysis of glycerol to produce 1,2-PD. In order to achieve high selectivity to 1,2-PD, rapid hydrogenation of the acetol intermediate is required as acetol is known to be active to produce other un-desired products via reactions between acetol and alcohols $[9,31,34,35]$. Thus, a major challenge of the glycerol hydrogenolysis process without adding molecular hydrogen is to ensure a fast hydrogenation of acetol compared to the other side reactions caused by acetol to produce undesired by-products. Hence a catalyst with high activity for dehydration, hydrogenation and methanol steam reforming would be desirable for a high yield and selectivity to 1,2-PD. We have previously reported that the activity of a $\mathrm{Cu} / \mathrm{ZnO} / \mathrm{Al}_{2} \mathrm{O}_{3}$ catalyst to produce 1,2-PD in the hydrogenolysis of glycerol using molecular hydrogen is dependent on the catalyst preparation method. Among the three preparation methods, namely, alkaline co-precipitation, impregnation and oxalate gel-co-precipitation, the catalyst prepared by the gel-co-precipitation method is the most active and selective $[9,36]$. Furthermore, $\mathrm{Cu} / \mathrm{ZnO} / \mathrm{Al}_{2} \mathrm{O}_{3}$ prepared by the gel-co-precipitation method has also been reported to be more active for steam reforming of methanol $[37,38]$. The main focus of this paper is to investigate the effect of $\mathrm{Ni}$ on the activity of a $\mathrm{Cu} / \mathrm{ZnO} / \mathrm{Al}_{2} \mathrm{O}_{3}$ catalyst prepared via oxalate gel-coprecipitation for the hydrogenolysis of glycerol using the in situ hydrogen produced via methanol steam reforming as illustrated in Figure 1. Ni was chosen because Ni has 
been reported to be active for both glycerol hydrogenolysis and methanol steam reforming [39-41] and it is less expensive than precious metals such as $\mathrm{Pt}$ and less active for $\mathrm{C}-\mathrm{C}$ bond cleavage $[42,43]$. The characterization and activity of $\mathrm{Cu} / \mathrm{ZnO} / \mathrm{Al}_{2} \mathrm{O}_{3}$ catalysts prepared by two different methods, namely, oxalate gel-co-precipitation and sodium carbonate co-precipitation were also reported as this provided a rational for adding $\mathrm{Ni}$ as a promoter to the $\mathrm{Cu} / \mathrm{ZnO} / \mathrm{Al}_{2} \mathrm{O}_{3}$ catalyst prepared by the oxalate gel-co-precipitation method.

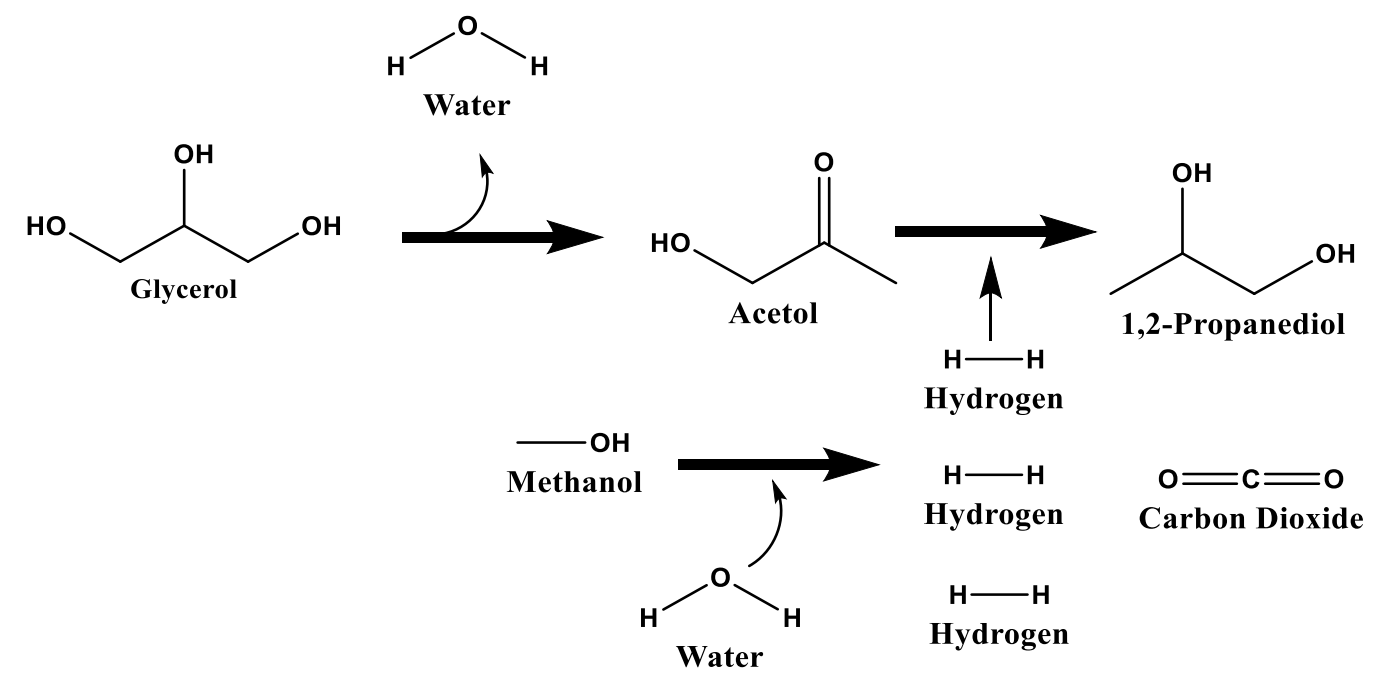

Figure 1. Reaction pathway of glycerol hydrogenolysis process using in situ hydrogen produced from methanol steam reforming.

\section{Results and Discussion}

\subsection{Catalyst Characterization}

\subsubsection{Acidity of the Catalysts}

The $\mathrm{NH}_{3}$ temperature programmed desorption (TPD) technique was used to investigate the acidity of the catalysts. The $\mathrm{Cu} / \mathrm{ZnO} / \mathrm{Al}_{2} \mathrm{O}_{3}$ catalysts prepared via oxalate gel-co-precipitation and sodium carbonate co-precipitation referred to as $\mathrm{Cu} / \mathrm{ZnO} / \mathrm{Al}_{2} \mathrm{O}_{3}-\mathrm{OA}$ and $\mathrm{Cu} / \mathrm{ZnO} / \mathrm{Al}_{2} \mathrm{O}_{3}-\mathrm{Na}$ respectively. The $\mathrm{NH}_{3}$ desorption profiles for the $\mathrm{Cu} / \mathrm{ZnO} / \mathrm{Al}_{2} \mathrm{O}_{3}-\mathrm{OA}$ and $\mathrm{Cu} / \mathrm{ZnO} / \mathrm{Al}_{2} \mathrm{O}_{3}-\mathrm{Na}$ have been presented in our previous work [9] and the desorption data are listed in Table 1. The $\mathrm{NH}_{3}$ TPD data for $\mathrm{Cu} / \mathrm{ZnO} / \mathrm{Al}_{2} \mathrm{O}_{3}-\mathrm{OA}$ catalysts with added $\mathrm{Ni}$ are listed in Table 1 and Figure 2 . The $\mathrm{Cu} / \mathrm{ZnO} / \mathrm{Al}_{2} \mathrm{O}_{3}-\mathrm{Na}$ catalyst has mainly acid sites with weak acidity ranging from 107 to $392{ }^{\circ} \mathrm{C}$ and very low total number of acidic sites, while $\mathrm{Cu} / \mathrm{ZnO} / \mathrm{Al}_{2} \mathrm{O}_{3}-\mathrm{OA}$ possesses both moderate and strong acidic sites corresponding to the desorption peaks ranging from 290 to $470{ }^{\circ} \mathrm{C}$ and from 590 to $800{ }^{\circ} \mathrm{C}$ respectively. It is noted that the strong acidic sites are a majority, which can facilitate the glycerol dehydration step. More acidic sites are being provided by $\mathrm{Cu} / \mathrm{ZnO} / \mathrm{Al}_{2} \mathrm{O}_{3}-\mathrm{OA}$ compared to $\mathrm{Cu} / \mathrm{ZnO} / \mathrm{Al}_{2} \mathrm{O}_{3}-\mathrm{Na}$ due to the smaller particle size, which will be investigated in the later section. Therefore, the oxalate gel-co-precipitation method can significantly enhance the number of acidic sites and the strength of acidity. Since dehydration requires acidic sites, the $\mathrm{Cu} / \mathrm{ZnO} / \mathrm{Al}_{2} \mathrm{O}_{3}-\mathrm{OA}$ catalyst was chosen to study the promoting effect of $\mathrm{Ni}$ on the hydrogenolysis of glycerol with methanol steam reforming. The effect of $\mathrm{Ni}$ loading on the acidity of a $\mathrm{Cu} / \mathrm{ZnO} / \mathrm{Al}_{2} \mathrm{O}_{3}$-OA catalyst is presented in Figure 2. With different amounts of Ni loading, three distinct peaks representing weak, moderate and strong acidic sites were observed for all the catalysts with three different $\mathrm{Ni}$ loadings $(0 \%, 1 \%$ and $5 \%)$ indicating that the acidic strength of the catalysts was not changed as no new desorption peak was generated by adding Ni. As Ni loading increased, the peak of the strong acidic sites ranging from 590 to $800{ }^{\circ} \mathrm{C}$ with the maximum desorption peak at $683^{\circ} \mathrm{C}$ shrunk, suggesting a smaller amount of strong acidic sites as shown in Table 1 . When $1 \% \mathrm{Ni}$ was loaded, the number of strong acidic sites slightly decreased from 0.075 to $0.072 \mathrm{mmolNH}_{3} / \mathrm{g}$-cat; 
when the Ni loading was increased to $5 \%$, the number of strong acidic sites decreased significantly to $0.030 \mathrm{mmolNH}_{3} / \mathrm{g}$-cat. It is possible that when $\mathrm{Ni}$ was added, some strong acidic sites were blocked by $\mathrm{Ni}$. This negative effect of $\mathrm{Ni}$ on the acidity of the catalyst behavior has been reported previously [44]. The weak and moderate acidic sites were not significantly affected by the Ni loading, even though the adsorption peak ranging from 290 to $470{ }^{\circ} \mathrm{C}$ without Ni loading was observed to be slightly lower than those with $1 \%$ and $5 \%$ Ni loading.

Table 1. Effect of $\mathrm{Ni}$ on the acidity of $\mathrm{Cu} / \mathrm{ZnO} / \mathrm{Al}_{2} \mathrm{O}_{3}-\mathrm{OA}$ catalysts.

\begin{tabular}{ccc}
\hline Catalysts & Number of Acidic Sites & Total Acidic Sites \\
\hline & mmolNH $_{3} /$ g-cat & mmolNH $_{3} /$ g-cat \\
\hline $\mathrm{Cu} / \mathrm{ZnO} / \mathrm{Al}_{2} \mathrm{O}_{3}-\mathrm{Na}^{1}$ & $0.04\left(107.0-392.0^{\circ} \mathrm{C}\right)$ & 0.040 \\
$\mathrm{Cu} / \mathrm{ZnO} / \mathrm{Al}_{2} \mathrm{O}_{3}-\mathrm{OA}^{1}$ & $0.216\left(50.0-290.0{ }^{\circ} \mathrm{C}\right)$ & 0.347 \\
& $0.056\left(290.0-470.0{ }^{\circ} \mathrm{C}\right)$ & \\
& $0.075\left(590.0-800.0{ }^{\circ} \mathrm{C}\right)$ & \\
& $0.198\left(50.0-290.0{ }^{\circ} \mathrm{C}\right)$ & 0.342 \\
& $0.072\left(290.0-470.0{ }^{\circ} \mathrm{C}\right)$ & \\
$5 \%$ (molar) $\mathrm{Ni} / \mathrm{Cu} / \mathrm{ZnO} / \mathrm{Al}_{2} \mathrm{O}_{3}-\mathrm{OA}^{2}$ & $0.072\left(590.0-800.0^{\circ} \mathrm{C}\right)$ & \\
& $0.197\left(50.0-590.0{ }^{\circ} \mathrm{C}\right)$ & 0.298 \\
& $0.071\left(290.0-470.0{ }^{\circ} \mathrm{C}\right)$ & \\
& $0.030\left(590.0-800.0{ }^{\circ} \mathrm{C}\right)$ & \\
& &
\end{tabular}

${ }^{1} \mathrm{Cu} / \mathrm{Zn} / \mathrm{Al}($ molar $)=35 / 35 / 30 ;{ }^{2} \mathrm{Ni} / \mathrm{Cu} / \mathrm{Zn} / \mathrm{Al}($ molar $)=1 / 34.5 / 34.5 / 30 ;{ }^{3} \mathrm{Ni} / \mathrm{Cu} / \mathrm{Zn} / \mathrm{Al}($ molar $)=5.0 / 32.5 / 32.5 / 30.0$.

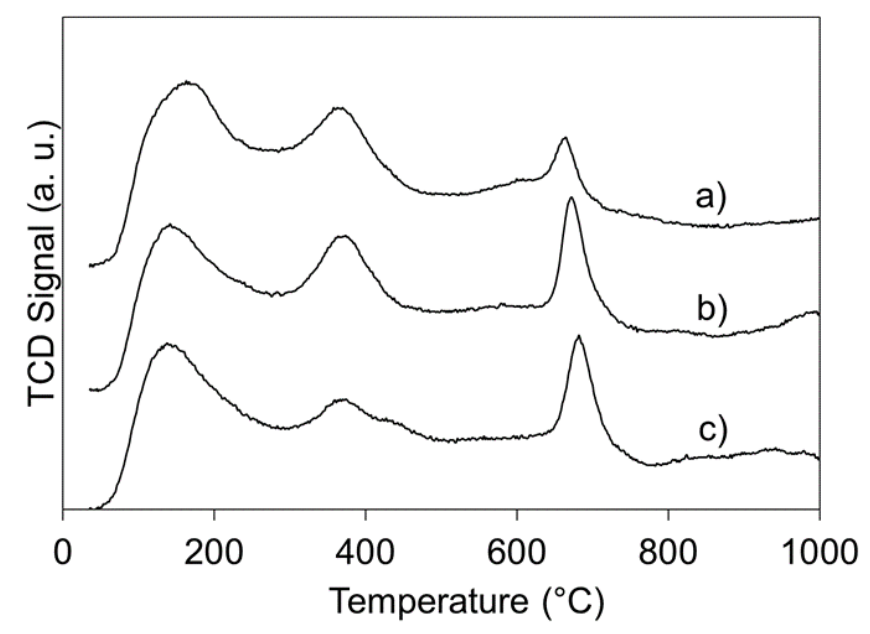

Figure 2. $\mathrm{NH}_{3}$ temperature programmed desorption (TPD) profiles for $\mathrm{Ni} / \mathrm{Cu} / \mathrm{ZnO} / \mathrm{Al}_{2} \mathrm{O}_{3}-\mathrm{OA}$ with different amounts of $\mathrm{Ni}$ loading (molar). (a) Ni/Cu/Zn/Al (molar) =5/32.5/32.5/30, (b) Ni/Cu/Zn/Al $($ molar $)=1 / 34.5 / 34.5 / 30,\left(\right.$ c) $\mathrm{Cu} / \mathrm{Zn} / \mathrm{Al}($ molar $)=35 / 35 / 30$. Conditions: $5 \% \mathrm{NH}_{3}$ balanced by Ar, $120 \mathrm{mg}$ catalyst, temperature ramp $5{ }^{\circ} \mathrm{C} / \mathrm{min}$, flow rate $30 \mathrm{~mL} / \mathrm{min}$. All traces have been displaced for clarity.

\subsubsection{Temperature Programmed Reduction}

The reducibility of the catalysts was characterized by a temperature programmed reduction (TPR) technique. The TPR profiles for the calcined $\mathrm{CuO} / \mathrm{ZnO} / \mathrm{Al}_{2} \mathrm{O}_{3}-\mathrm{OA}$ and the $\mathrm{CuO} / \mathrm{ZnO} / \mathrm{Al}_{2} \mathrm{O}_{3}-\mathrm{Na}$ catalysts have been already reported [9]. All the profiles indicated that the reduction of the catalysts could be completed before $300{ }^{\circ} \mathrm{C}$ suggesting that reduction at $300{ }^{\circ} \mathrm{C}$ is sufficient to reduce the $\mathrm{CuO} / \mathrm{ZnO} / \mathrm{Al}_{2} \mathrm{O}_{3}$ catalysts. Figure 3 shows the TPR profiles of $\mathrm{NiO} / \mathrm{CuO} / \mathrm{ZnO} / \mathrm{Al}_{2} \mathrm{O}_{3}-\mathrm{OA}, \mathrm{CuO} / \mathrm{ZnO} / \mathrm{Al}_{2} \mathrm{O}_{3}-\mathrm{OA}$ and $\mathrm{NiO}$ only. The characteristic $p$ values were calculated in the Supplementary Document A2 to verify that the experiments were carried out with absence of significant reducing agent concentration gradients along the catalyst bed. From the graph, it can be seen that both $\mathrm{NiO} / \mathrm{CuO} / \mathrm{ZnO} / \mathrm{Al}_{2} \mathrm{O}_{3}-\mathrm{OA}$ and $\mathrm{CuO} / \mathrm{ZnO} / \mathrm{Al}_{2} \mathrm{O}_{3}-\mathrm{OA}$ catalysts show the reduction peaks between 180 and $330{ }^{\circ} \mathrm{C}$ with the peak maxima at around $250^{\circ} \mathrm{C}$. The reduction peak for $\mathrm{NiO}$ starts at $250^{\circ} \mathrm{C}$ and ends at $370^{\circ} \mathrm{C}$ with the peak 
maxima at $310^{\circ} \mathrm{C}$. No distinctive peak is observed in the $\mathrm{NiO} / \mathrm{CuO} / \mathrm{ZnO} / \mathrm{Al}_{2} \mathrm{O}_{3}-\mathrm{OA}$ profile between 300 and $400{ }^{\circ} \mathrm{C}$ compared with the profile for $\mathrm{CuO} / \mathrm{ZnO} / \mathrm{Al}_{2} \mathrm{O}_{3}-\mathrm{OA}$. This suggests that $\mathrm{NiO}$ and $\mathrm{CuO}$ are well mixed and both oxides can be effectively reduced at $300{ }^{\circ} \mathrm{C}$ [45]. Two shoulder peaks were observed for both $\mathrm{NiO} / \mathrm{CuO} / \mathrm{ZnO} / \mathrm{Al}_{2} \mathrm{O}_{3}-\mathrm{OA}$ and $\mathrm{CuO} / \mathrm{ZnO} / \mathrm{Al}_{2} \mathrm{O}_{3}-\mathrm{OA}$. The peak between 185 and $210{ }^{\circ} \mathrm{C}$ is due to the formation of bulk $\mathrm{CuO}$ and the broad shoulder peak between 270 and $300^{\circ} \mathrm{C}$ is possibly due to the reduction of $\mathrm{Cu}^{+}$to $\mathrm{Cu}^{0}$ [9]. A very broad peak after $300^{\circ} \mathrm{C}$ was possibly due to the reduction of $\mathrm{ZnO}$.

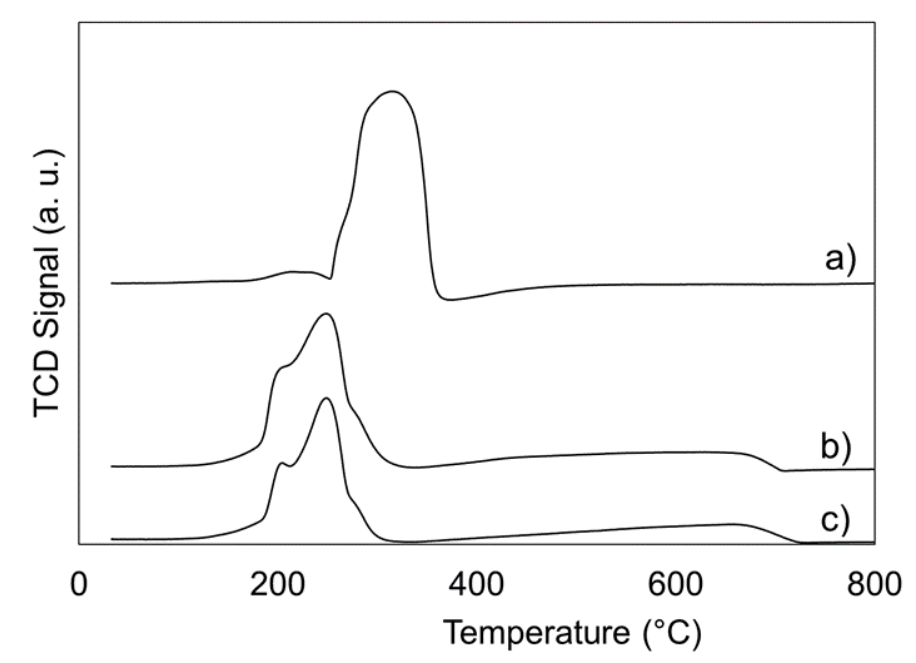

Figure 3. $\mathrm{H}_{2}$ TPR profiles for $\mathrm{Ni} / \mathrm{Cu} / \mathrm{ZnO} / \mathrm{Al}_{2} \mathrm{O}_{3}-\mathrm{OA}$ with different amounts of $\mathrm{Ni}$ loading (molar). (a) $\mathrm{NiO},(\mathbf{b}) \mathrm{Ni} / \mathrm{Cu} / \mathrm{Zn} / \mathrm{Al}$ (molar) = 5/32.5/32.5/30, (c) $\mathrm{Cu} / \mathrm{Zn} / \mathrm{Al}$ (molar) = 35/35/30. Conditions: 5\% $\mathrm{H}_{2}$ balanced by Ar, catalyst amount: (a) $20 \mathrm{mg}$, (b,c) $50 \mathrm{mg}$, temperature ramp $5{ }^{\circ} \mathrm{C} / \mathrm{min}$, flow rate $30 \mathrm{~mL} / \mathrm{min}$. $p$ value $18-20 \mathrm{~K}$. All traces have been displaced for clarity.

\subsubsection{Transmission Electron Microscopy}

The $\mathrm{CuO} / \mathrm{ZnO} / \mathrm{Al}_{2} \mathrm{O}_{3}-\mathrm{OA}$ and $\mathrm{CuO} / \mathrm{ZnO} / \mathrm{Al}_{2} \mathrm{O}_{3}-\mathrm{Na}$ catalysts were characterized by transmission electron microscopy (TEM) to study the effect of preparation method on the catalyst morphology as shown in Figure 4. From Figure $4 a, b$, it can be observed that for the catalyst prepared by oxalate gel-co-precipitation method, the particle shape is spherical and the particles are very uniformly distributed suggested by a smaller calculated standard deviation (SD). Figure 5 compared the histograms of the particle size distributions for the catalysts prepared by these two methods. The calculated mean particle size for the $\mathrm{Cu} / \mathrm{ZnO} / \mathrm{Al}_{2} \mathrm{O}_{3}-\mathrm{OA}$ catalyst is $10.41 \mathrm{~nm}$ with $\mathrm{SD}$ of 2.04 . For the $\mathrm{Cu} / \mathrm{ZnO} / \mathrm{Al}_{2} \mathrm{O}_{3}-\mathrm{Na}$ catalyst, the particles are more elliptical and the average size of the major axis is $18.83 \mathrm{~nm}$ and $\mathrm{SD}$ is 4.05 , which is much larger than the $\mathrm{Cu} / \mathrm{ZnO} / \mathrm{Al}_{2} \mathrm{O}_{3}-\mathrm{OA}$ catalyst and the size distribution is much wider as illustrated in Figure 5. This observation is in a good agreement with the previous literature reports using these preparation methods $[9,46]$. 

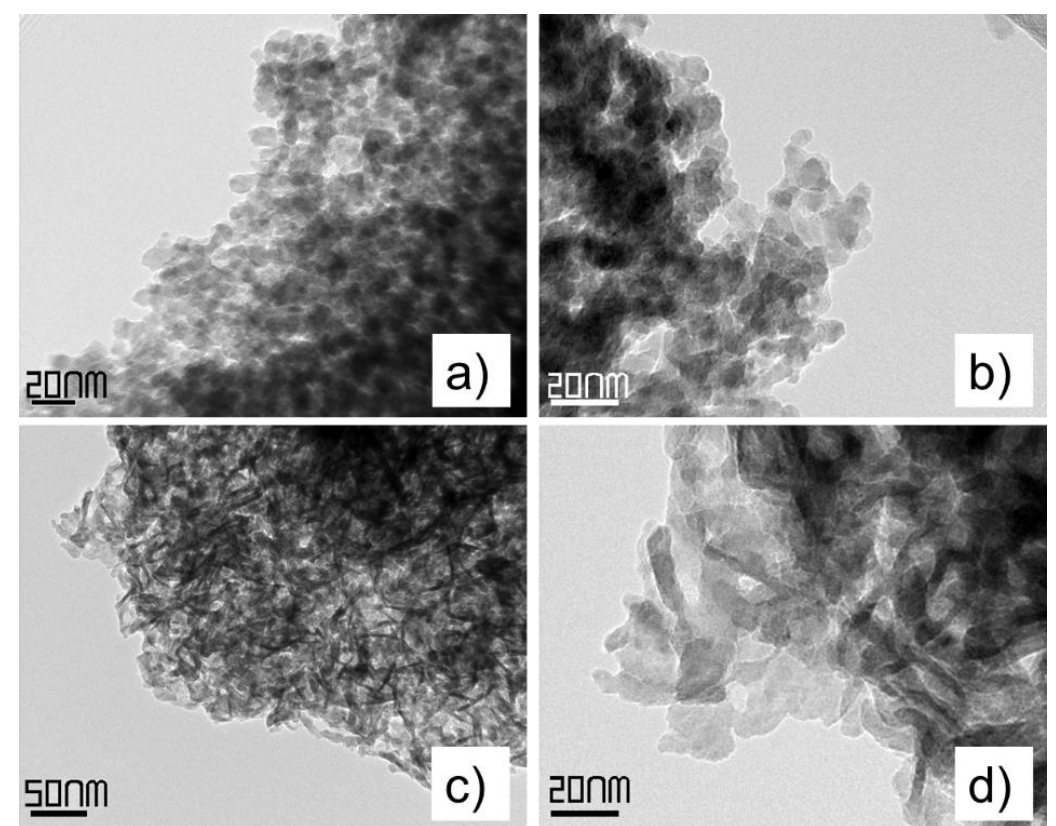

Figure 4. Transmission electron microscopy (TEM) images of: $(\mathbf{a}, \mathbf{b}) \mathrm{CuO} / \mathrm{ZnO} / \mathrm{Al}_{2} \mathrm{O}_{3}$ catalyst prepared via oxalate gel-co-precipitation; $(\mathbf{c}, \mathbf{d}) \mathrm{CuO} / \mathrm{ZnO} / \mathrm{Al}_{2} \mathrm{O}_{3}$ catalysts prepared via $\mathrm{Na}_{2} \mathrm{CO}_{3}$ co-precipitation. $\mathrm{Cu} / \mathrm{Zn} / \mathrm{Al}($ molar $)=35 / 35 / 30$.
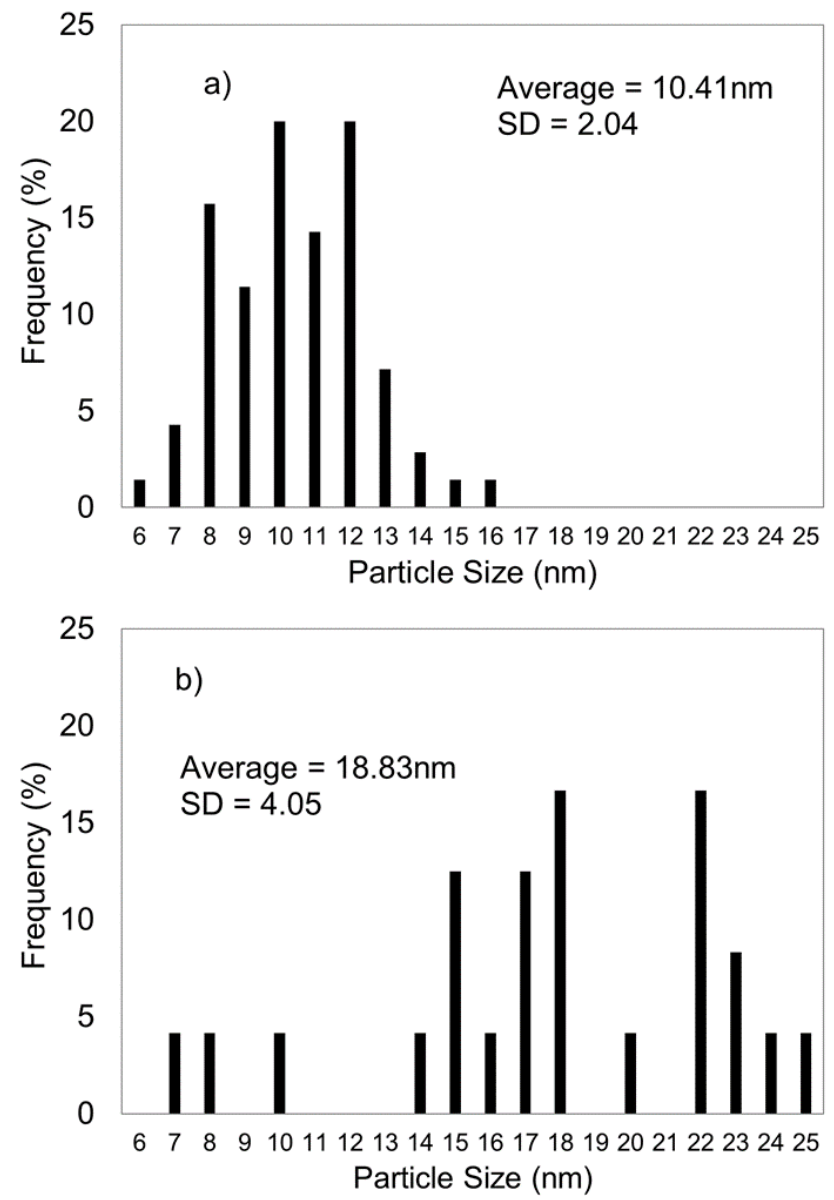

Figure 5. Histograms of the particle size distribution determined by TEM. (a) $\mathrm{CuO} / \mathrm{ZnO} / \mathrm{Al}_{2} \mathrm{O}_{3}$ catalyst prepared via oxalate gel-co-precipitation; (b) $\mathrm{CuO} / \mathrm{ZnO} / \mathrm{Al}_{2} \mathrm{O}_{3}$ catalysts prepared via $\mathrm{Na}_{2} \mathrm{CO}_{3}$ co-precipitation. $\mathrm{Cu} / \mathrm{Zn} / \mathrm{Al}$ (molar) = 35/35/30. 


\subsubsection{Thermal Gravimetric Analysis}

In our previous work, the thermogravimetric analysis (TGA) results for the $\mathrm{Cu} / \mathrm{ZnO} / \mathrm{Al}_{2} \mathrm{O}_{3}-\mathrm{OA}$ and $\mathrm{Cu} / \mathrm{ZnO} / \mathrm{Al}_{2} \mathrm{O}_{3}-\mathrm{Na}$ catalyst have been presented [9]. The $\mathrm{Cu} / \mathrm{ZnO} / \mathrm{Al}_{2} \mathrm{O}_{3}-\mathrm{OA}$ and $\mathrm{Cu} / \mathrm{ZnO} / \mathrm{Al}_{2} \mathrm{O}_{3}-\mathrm{Na}$ were completely decomposed at 325 and $630{ }^{\circ} \mathrm{C}$ respectively. The oxalate gel-coprecipitation method favors a chemical homogenous phase of $\mathrm{Cu}$ and $\mathrm{Zn}$, and the lower calcination temperature compared with $\mathrm{Na}_{2} \mathrm{CO}_{3}$ co-precipitation method can help to avoid the sintering of the particles during the calcination process. Figure 6 illustrates the TGA results for the oxalates of $\mathrm{Cu} / \mathrm{ZnO} / \mathrm{Al}_{2} \mathrm{O}_{3}-\mathrm{OA}$ and $\mathrm{Ni} / \mathrm{Cu} / \mathrm{ZnO} / \mathrm{Al}_{2} \mathrm{O}_{3}-\mathrm{OA}$. The temperature difference was used to demonstrate the heat flow during the thermal decomposition of metal oxalates process. For a $\mathrm{Cu} / \mathrm{ZnO} / \mathrm{Al}_{2} \mathrm{O}_{3}-\mathrm{OA}$ catalyst, the weight loss completes at $330^{\circ} \mathrm{C}$ and a small weight loss peak is observed at around $210^{\circ} \mathrm{C}$ indicating a thermal decomposition of a mixed metal oxalate with a higher $\mathrm{Cu}$ content as shown in Figure 6a, which is in agreement with the results we previously published [9]. When $\mathrm{Ni}$ was added, a similar trend was observed from Figure $6 \mathrm{~b}$ that the weight loss started at $165^{\circ} \mathrm{C}$ and completed at $330{ }^{\circ} \mathrm{C}$ with the highest rate of weight lost at $310^{\circ} \mathrm{C}$ suggested by the temperature difference profile. A positive temperature difference reveals that the thermal decomposition of metal oxalate is an exothermic reaction. As the decomposition rate increased, the temperature difference was also increased and reached its maxima at $310^{\circ} \mathrm{C}$ due to the maximum heat released associated with the metal oxalate decomposition. No separate peak was found for the decomposition of nickel oxalate suggesting that Ni was well mixed with other metals; this is also supported by the X-ray diffraction (XRD) data in the latter discussion. Therefore, the calcination temperature of $360^{\circ} \mathrm{C}$ would be sufficient for the decomposition of all the catalyst precursors.
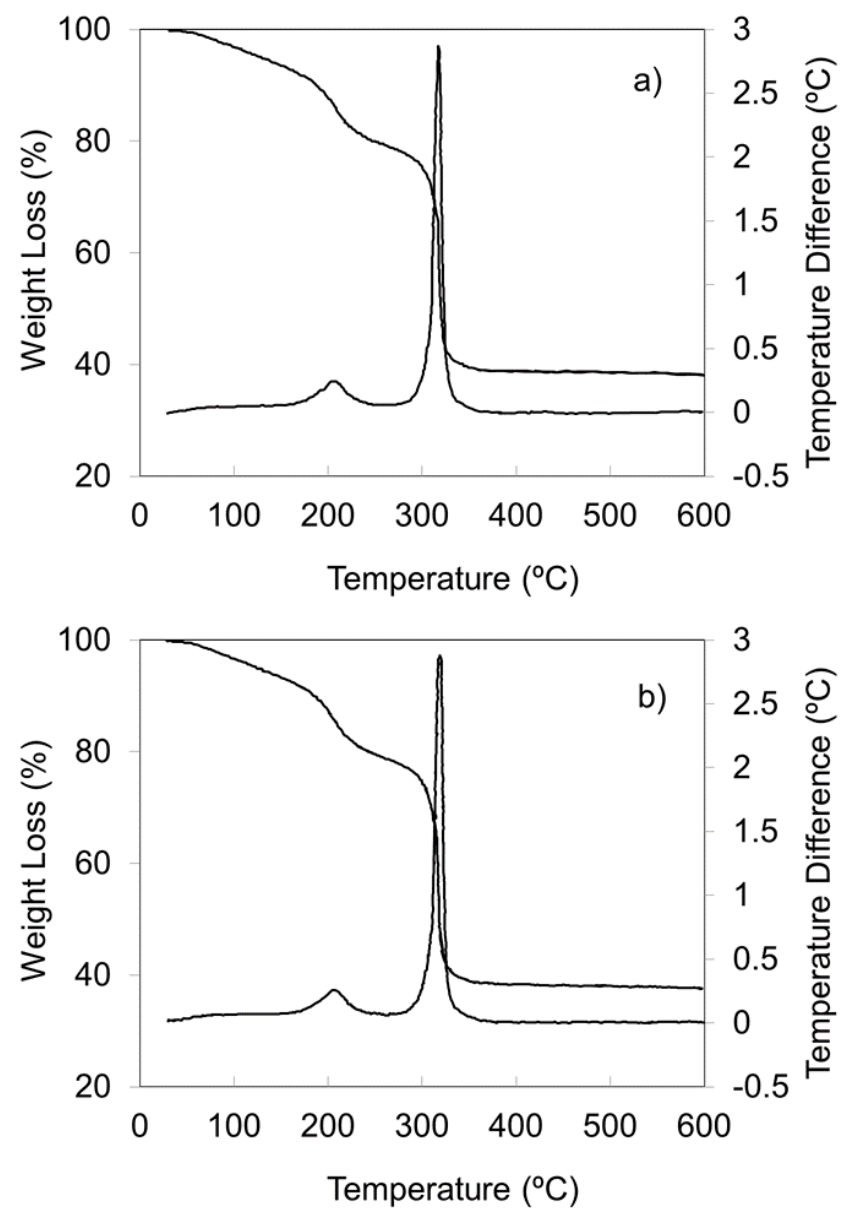

Figure 6. Thermogravimetric analysis (TGA) profiles for: (a) $\mathrm{Cu} / \mathrm{ZnO} / \mathrm{Al}_{2} \mathrm{O}_{3}-\mathrm{OA}$ oxalate, $\mathrm{Cu} / \mathrm{Zn} / \mathrm{Al}$ $($ molar $)=35 / 35 / 30 ;\left(\right.$ b) $\mathrm{Ni} / \mathrm{Cu} / \mathrm{ZnO} / \mathrm{Al}_{2} \mathrm{O}_{3}-\mathrm{OA}$ oxalate, $\mathrm{Ni} / \mathrm{Cu} / \mathrm{Zn} / \mathrm{Al}($ molar $)=5 / 32.5 / 32.5 / 30$. 


\subsubsection{Diffuse Reflectance Infrared Fourier Transform}

Figure 7 shows the Diffuse Reflectance Infrared Fourier Transform (DRIFT) spectra of adsorbed CO on the reduced catalysts at ambient temperature. At a CO equilibrium pressure of $50 \mathrm{~Pa}$, two bands were observed for the sample of $\mathrm{Cu} / \mathrm{ZnO} / \mathrm{Al}_{2} \mathrm{O}_{3}-\mathrm{OA}$ catalyst. The band appears at $2106 \mathrm{~cm}^{-1}$, which decreases in intensity with decreasing equilibrium $\mathrm{CO}$ pressure and disappears after evacuation, corresponding to the absorbance of $\mathrm{Cu}^{0}-\mathrm{CO}$ species $[47,48]$. The band at $2025 \mathrm{~cm}^{-1}$ still remains even after evacuation at ambient temperature, and it is associated with the carbonyls linearly adsorbed on the $\mathrm{Cu}^{0}$ atoms with lower coordination numbers [48]. It is worth noting that the band at $2025 \mathrm{~cm}^{-1}$ shifts to $2005 \mathrm{~cm}^{-1}$ after evacuation. This is related to the decrease in the coverage of $\mathrm{CO}$ on the $\mathrm{Cu}$ surface during evacuation, which leads to a decrease in the dipole-dipole coupling of the adsorbed $\mathrm{CO}$ molecules and further a band shift toward lower wavenumbers [49]. For the Ni-doped $\mathrm{Cu} / \mathrm{ZnO} / \mathrm{Al}_{2} \mathrm{O}_{3}-\mathrm{OA}$ catalysts, a new band at $2057 \mathrm{~cm}^{-1}$ was observed, which can be assigned to the stretching vibration of the linear-bonded $\mathrm{CO}$ on the reduced $\mathrm{Ni}$. This band vanished after evacuation. In general, the linear-bonded $\mathrm{CO}$ on $\mathrm{Ni}$ appears in the region of 2020-2080 $\mathrm{cm}^{-1}$, and the position of the band is a reflection of the crystallinity and dispersion of Ni. According to the literature [50,51], the band at $2057 \mathrm{~cm}^{-1}\left(>2050 \mathrm{~cm}^{-1}\right)$ implies that $\mathrm{Ni}$ exists in a high dispersion and a low crystallinity, which is in a good agreement with the results of XRD. Another band corresponding to bridged-bonded CO on Ni usually can be observed in the region of 1990-1940 $\mathrm{cm}^{-1}$ [50]. In this case, however, the band cannot be distinguished because it overlaps with the signal of the carbonyls linearly adsorbed on the $\mathrm{Cu}^{0}$ atoms.

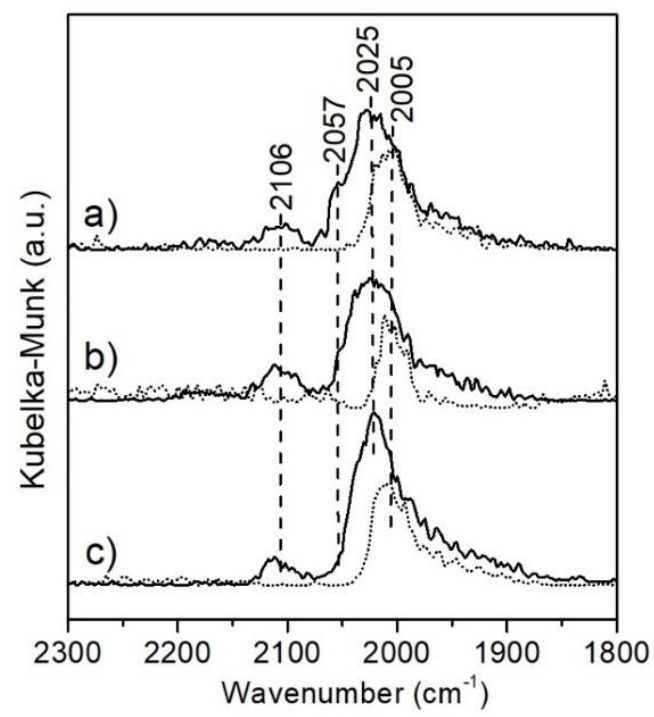

Figure 7. Diffuse Reflectance Infrared Fourier Transform (DRIFT) spectra of CO adsorbed on the reduced catalysts at ambient temperature. Solid: equilibrium pressure of $50 \mathrm{~Pa} \mathrm{CO}$; dash: after evacuation. Catalysts: $\mathrm{Ni} / \mathrm{Cu} / \mathrm{ZnO} / \mathrm{Al}_{2} \mathrm{O}_{3}-\mathrm{OA}$, (a) Ni/Cu/Zn/Al (molar) =5/32.5/32.5/30, (b) Ni/Cu/Zn/Al $($ molar $)=1 / 34.5 / 34.5 / 30$, (c) $\mathrm{Cu} / \mathrm{Zn} / \mathrm{Al}($ molar $)=35 / 35 / 30$. All traces have been displaced for clarity.

\subsubsection{X-ray Diffraction and Other Physicochemical Properties}

The crystalline phases for all the catalysts were investigated by XRD. The XRD pattern for $\mathrm{CuO} / \mathrm{ZnO} / \mathrm{Al}_{2} \mathrm{O}_{3}-\mathrm{OA}$ and $\mathrm{CuO} / \mathrm{ZnO} / \mathrm{Al}_{2} \mathrm{O}_{3}-\mathrm{Na}$ have been previously reported. It showed that for the catalyst prepared via the gel-co-precipitation method the particles were very well mixed and homogeneously distributed through the catalyst as suggested by much broader and low intensity peaks for $\mathrm{CuO}$ and $\mathrm{ZnO}[9,38,46]$. Figure 8 illustrates the $\mathrm{XRD}$ patterns for the $\mathrm{CuO} / \mathrm{ZnO} / \mathrm{Al}_{2} \mathrm{O}_{3}-\mathrm{OA}$ catalysts with different $\mathrm{Ni}$ loadings. It can be observed that the crystal structures of the catalysts are not significantly affected by Ni loadings, the $2 \theta$ peaks located at $35.6^{\circ}$ and $38.8^{\circ}$ represent $\mathrm{CuO}$ and the $2 \theta$ peak located at $31.9^{\circ}$ represents $\mathrm{ZnO}[6,9,38]$; the particle sizes of $\mathrm{CuO}$ and $\mathrm{ZnO}$ calculated by Scherer's equation are also not significantly affected as shown in Table 2. The peak for NiO is not 
observed from the XRD patterns for the catalysts suggesting that $\mathrm{NiO}$ particles are in a low crystallinity and highly dispersed in the catalyst or the Ni loadings are so small that the peaks for $\mathrm{NiO}$ cannot be clearly observed which has been reported $[52,53]$. The copper surface area of the catalyst with different amounts of $\mathrm{Ni}$ loading are listed in Table 2, where addition of $1 \% \mathrm{Ni}$ into the $\mathrm{Cu} / \mathrm{ZnO} / \mathrm{Al}_{2} \mathrm{O}_{3}-\mathrm{OA}$ catalyst causes a 3.7\% reduction of $\mathrm{Cu}$ surface area, while a $5 \% \mathrm{Ni}$ loading reduces the $\mathrm{Cu}$ surface area by $16.0 \%$. This reduction of $\mathrm{Cu}$ surface area can significantly affect the activity of the catalyst which will be discussed later. Table 2 also lists the actual metal molar content measured by an Inductively coupled plasma (ICP) technique, the actual values of the metal content for the $\mathrm{Cu} / \mathrm{ZnO} / \mathrm{Al}_{2} \mathrm{O}_{3}-\mathrm{OA}$ catalysts with different $\mathrm{Ni}$ loading are not significantly changed compared with the feed composition during the preparation.

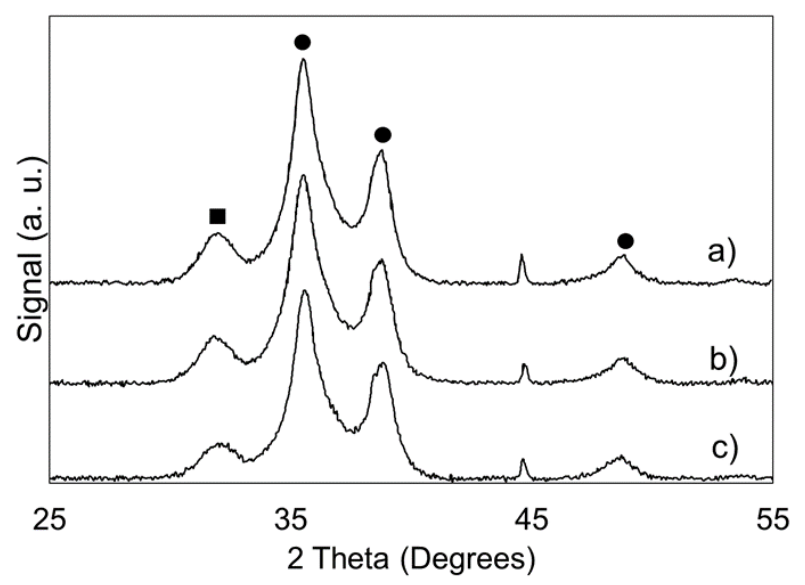

Figure 8. X-ray diffraction (XRD) patterns for $\mathrm{Ni} / \mathrm{Cu} / \mathrm{ZnO} / \mathrm{Al}_{2} \mathrm{O}_{3}-\mathrm{OA}$ with different amounts of $\mathrm{Ni}$ loading (molar). (a) Ni/Cu/Zn/Al (molar) = 5/32.5/32.5/30, (b) Ni/Cu/Zn/Al (molar) = 1/34.5/34.5/30, (c) $\mathrm{Cu} / \mathrm{Zn} / \mathrm{Al}($ molar $)=35 / 35 / 30$. $\mathrm{CuO}, \mathbf{Z n O}$. All traces have been displaced for clarity.

Table 2. Some physicochemical properties of the $\mathrm{Ni} / \mathrm{Cu} / \mathrm{ZnO} / \mathrm{Al}_{2} \mathrm{O}_{3}-\mathrm{OA}$.

\begin{tabular}{|c|c|c|c|c|}
\hline & $\begin{array}{c}\text { Crystal Size of } \mathrm{CuO}^{1} \\
\mathrm{~nm}\end{array}$ & $\begin{array}{c}\text { Crystal Size of } \mathrm{ZnO}^{1} \\
\mathrm{~nm}\end{array}$ & $\begin{array}{c}\text { Cu Surface Area } \\
\text { m²/g-cat }^{2}\end{array}$ & $\begin{array}{c}\text { Metal Composition }{ }^{2} \\
\text { (Theoretical Value) }\end{array}$ \\
\hline $0 \% \mathrm{Ni}$ & 14.7 & 10.2 & 18.8 & $\begin{array}{c}37.1 / 36.4 / 26.5 \\
(35.0 / 35.0 / 30.0)\end{array}$ \\
\hline $1 \% \mathrm{Ni}$ & 14.2 & 11.6 & 18.1 & $\begin{array}{c}0.9 / 36.2 / 35.6 / 27.3 \\
(1.0 / 34.5 / 34.5 / 30.0)\end{array}$ \\
\hline $5 \% \mathrm{Ni}$ & 15.0 & 10.9 & 15.8 & $\begin{array}{c}4.7 / 33.1 / 34.4 / 27.8 \\
(5.0 / 32.5 / 32.5 / 30.0)\end{array}$ \\
\hline
\end{tabular}

${ }^{1}$ Calculated by Scherrer's equation, ${ }^{2}$ Molar ratio of Ni/Cu/Zn/Al measured by ICP.

\subsection{Glycerol Hydrogenolysis with In Situ Hydrogen Produced from Methanol Steam Reforming}

\subsubsection{Effect of Preparation Method for $\mathrm{Cu} / \mathrm{ZnO} / \mathrm{Al}_{2} \mathrm{O}_{3}$ Catalysts}

The $\mathrm{Cu} / \mathrm{ZnO} / \mathrm{Al}_{2} \mathrm{O}_{3}-\mathrm{OA}$ catalyst has been reported to be more active than the $\mathrm{Cu} / \mathrm{ZnO} / \mathrm{Al}_{2} \mathrm{O}_{3}-\mathrm{Na}$ catalyst on both glycerol hydrogenolysis with external molecular hydrogen added [9] and methanol steam reforming [37,38]. The conversion of glycerol, selectivity of 1,2-PD and the yields of different products were calculated through the equations listed below, where " $\mathrm{i}$ " stands for each product/by-product formed from glycerol. The experimental results on glycerol hydrogenolysis with in situ hydrogen generated from methanol steam reforming are listed in Table 3. The space-time yields are provided from Tables S1-S4 in the Supplementary Material. It can be clearly observed in Table 3 that the glycerol conversion and 1,2-PD selectivity using a $\mathrm{Cu} / \mathrm{ZnO} / \mathrm{Al}_{2} \mathrm{O}_{3}-\mathrm{OA}$ catalyst are significantly higher than those using a $\mathrm{Cu} / \mathrm{ZnO} / \mathrm{Al}_{2} \mathrm{O}_{3}-\mathrm{Na}$ catalyst; the space-time yield of 1,2-PD using a $\mathrm{Cu} / \mathrm{ZnO} / \mathrm{Al}_{2} \mathrm{O}_{3}-\mathrm{OA}$ catalyst is about 10 times higher than that using a $\mathrm{Cu} / \mathrm{ZnO} / \mathrm{Al}_{2} \mathrm{O}_{3}-\mathrm{Na}$ 
catalyst as listed in Tables S1 and S2. When $\mathrm{Cu} / \mathrm{ZnO} / \mathrm{Al}_{2} \mathrm{O}_{3}-\mathrm{Na}$ was used, the selectivity of 1,2-PD was only $29.1 \%$ and the major by-products were acetol and some other higher molecular weight compounds. These higher molecular weight compounds were believed to be formed via condensation reactions of alcohols with acetol [9,35]. A significantly higher 1,2-PD selectivity obtained using $\mathrm{Cu} / \mathrm{ZnO} / \mathrm{Al}_{2} \mathrm{O}_{3}-\mathrm{OA}(70.7 \%)$ compared with the $\mathrm{Cu} / \mathrm{ZnO} / \mathrm{Al}_{2} \mathrm{O}_{3}-\mathrm{Na}$ catalyst $(29.1 \%)$ attributed to its superior activity on methanol steam reforming to provide more hydrogen for acetol hydrogenation, as revealed in Table 3, since the acetol yield and other undesired by-products yields in the product mixture were significantly lower. The higher conversion obtained with the $\mathrm{Cu} / \mathrm{ZnO} / \mathrm{Al}_{2} \mathrm{O}_{3}-\mathrm{OA}$ catalyst is attributed to the higher copper surface area and higher number of acidic sites and higher acidic strength. Professor Lemonidou's group also reported that a $\mathrm{Cu} / \mathrm{ZnO} / \mathrm{Al}_{2} \mathrm{O}_{3}-\mathrm{OA}$ catalyst was more active than a $\mathrm{Cu} / \mathrm{ZnO} / \mathrm{Al}_{2} \mathrm{O}_{3}-\mathrm{Na}$ catalyst in the hydrogenolysis of glycerol using hydrogen derived from steam reforming of methanol [29]. In their optimization study, the space-time yield for 1,2-PD was reported to be $12.1 \mathrm{mmol} / \mathrm{h}$.g-cat at $250{ }^{\circ} \mathrm{C}$ after $1 \mathrm{~h}$ reaction [30]; a very similar space-time yield for $1,2-\mathrm{PD}$ was found using the $\mathrm{Cu} / \mathrm{ZnO} / \mathrm{Al}_{2} \mathrm{O}_{3}$-OA catalyst at $220^{\circ} \mathrm{C}$, as listed in Table S2, which was calculated to be $11.8 \mathrm{mmol} / \mathrm{h}$.g-cat. The space-time yield of 1,2-PD was found to be slightly lower possibly due to a slightly lower reaction temperature. It was also reported that at $220^{\circ} \mathrm{C}$ a maximum yield of $50.6 \%$ was obtained at $220^{\circ} \mathrm{C}$ after $4 \mathrm{~h}$ reaction time; a similar 1,2-PD yield was also obtained, as listed in Table S2, that at the same reaction temperature, the yield of 1,2-PD at $4 \mathrm{~h}$ reaction time was found to be $46.1 \%$. Therefore, it is believed that the $\mathrm{Cu} / \mathrm{ZnO} / \mathrm{Al}_{2} \mathrm{O}_{3}-\mathrm{OA}$ catalyst is feasible for this reaction system. It is clear that the 1,2-PD selectivity strongly depends on the hydrogen supply, which is derived from methanol steam reforming in this reaction system. Higher ethylene glycol yield using a $\mathrm{Cu} / \mathrm{ZnO} / \mathrm{Al}_{2} \mathrm{O}_{3}-\mathrm{OA}$ catalyst (Table 3 ) is possibly due to the higher acidity of the catalyst and a higher hydrogen concentration generated by methanol steam reforming promoting the $\mathrm{C}-\mathrm{C}$ cleavage to produce more ethylene glycol. The $\mathrm{Cu}: \mathrm{Zn}: \mathrm{Al}$ molar ratio of 35:35:30 was chosen for this work after a metal composition study, as listed in Table 3. The composition study for $\mathrm{Cu} / \mathrm{ZnO} / \mathrm{Al}_{2} \mathrm{O}_{3}$ catalysts have been extensively reported and the optimum molar ratio of $\mathrm{Cu} / \mathrm{Zn}$ has been mostly reported to be 1 for both methanol steam reforming $[37,38,54]$ and glycerol hdyrogenolysis $[6,55,56]$. In this work, the molar ratio for $\mathrm{Cu} / \mathrm{Zn}$ of 1 was chosen and the molar content of aluminum was varied. The experimental results are shown in Table 3. A significant improvement for glycerol conversion and 1,2-PD selectivity was noticed when the aluminum molar content was increased from $10 \%$ to $30 \%$. If the aluminum molar content was further increased from $30 \%$ to $50 \%$, the glycerol conversion and 1,2-PD yield slightly dropped. Therefore, the catalyst with a $\mathrm{Cu} / \mathrm{Zn} / \mathrm{Al}$ molar ratio of 35/35/30 was the optimum ratio and was used for further study. The absence of external liquid to solid mass transfer limitation and intraparticle diffusion limitation were also verified via theoretical calculations provided in the Supplementary Document A3. It has been mathematically proven that the experiments were carried out in the reaction controlled regime.

$$
\begin{gathered}
\text { Conversion }_{\text {Glycerol }}=100 \%-\frac{n_{\text {Glycerol }}}{n_{\text {Glycerol }}+n_{1,2-P D}+n_{\text {Acetol }}+n_{E G}+n_{\text {Propanol }}+n_{\text {Others }}} \times 100 \%, \\
\text { Yield }_{i}=\frac{n_{i}}{n_{\text {Glycerol }}+n_{1,2-P D}+n_{\text {Acetol }}+n_{E G}+n_{\text {Propanol }}+n_{\text {Others }}} \times 100 \%, \\
\text { Selectivity } \\
=\frac{\text { Yield }_{i}}{\text { Conversion }_{\text {Glycerol }}} \times 100 \% .
\end{gathered}
$$


Table 3. Products distribution for glycerol hydrogenolysis with in situ $\mathrm{H}_{2}$ from methanol steam reforming over $\mathrm{Cu} / \mathrm{ZnO} / \mathrm{Al}_{2} \mathrm{O}_{3}-\mathrm{OA}$ and $\mathrm{Cu} / \mathrm{ZnO} / \mathrm{Al}_{2} \mathrm{O}_{3}-\mathrm{Na}$ catalysts ${ }^{1}$.

\begin{tabular}{cccccccc}
\hline Catalysts & $\begin{array}{c}\text { Glycerol } \\
\text { Conversion }\end{array}$ & $\begin{array}{c}\text { 1,2-PD } \\
\text { Selectivity }\end{array}$ & $\begin{array}{c}\text { 1,2-PD } \\
\text { Yield }\end{array}$ & $\begin{array}{c}\text { Acetol } \\
\text { Yield }\end{array}$ & $\begin{array}{c}\text { EG }^{\mathbf{5}} \\
\text { Yield }\end{array}$ & $\begin{array}{c}\text { Propanol } \\
\text { Yield }\end{array}$ & $\begin{array}{c}\text { Others } \\
\text { Yield }\end{array}$ \\
\hline $\mathrm{Cu} / \mathrm{ZnO} / \mathrm{Al}_{2} \mathrm{O}_{3}-\mathrm{Na}^{2}$ & 60.3 & 29.1 & 17.5 & 16.1 & 0.0 & 0.0 & 26.7 \\
$\mathrm{Cu} / \mathrm{ZnO} / \mathrm{Al}_{2} \mathrm{O}_{3}-\mathrm{OA}^{2}$ & 87.1 & 70.7 & 61.6 & 5.2 & 2.9 & 0.7 & 16.7 \\
$\mathrm{Cu} / \mathrm{ZnO} / \mathrm{Al}_{2} \mathrm{O}_{3}-\mathrm{OA}^{3}$ & 80.2 & 65.7 & 52.7 & 9.5 & 2.6 & 0.5 & 14.9 \\
$\mathrm{Cu} / \mathrm{ZnO} / \mathrm{Al}_{2} \mathrm{O}_{3}-\mathrm{OA}^{4}$ & 82.7 & 69.9 & 57.8 & 9.2 & 2.0 & 0.9 & 12.7 \\
\hline
\end{tabular}

${ }^{1}$ Reaction Conditions: $220{ }^{\circ} \mathrm{C}, 1.5 \mathrm{MPa} \mathrm{N}_{2}, 100 \mathrm{~g}$ feedstock mixture, $20 \mathrm{wt} \%$ glycerol, $32.2 \mathrm{wt} \%$ of water and $47.8 \mathrm{wt} \%$ methanol (water/methanol molar ratio $=1.2), 3 \mathrm{~g}$ catalyst, $500 \mathrm{RPM}, 8 \mathrm{~h} ;{ }^{2} \mathrm{Cu} / \mathrm{Zn} / \mathrm{Al}\left(\right.$ molar) $=35 / 35 / 30 ;{ }^{3} \mathrm{Cu} / \mathrm{Zn} / \mathrm{Al}$ $($ molar $)=45 / 45 / 10 ;{ }^{4} \mathrm{Cu} / \mathrm{Zn} / \mathrm{Al}($ molar $)=25 / 25 / 50 ;{ }^{5}$ EG: ethylene glycol .

\subsubsection{Effect of $\mathrm{Ni}$ as a Promoter for the $\mathrm{Cu} / \mathrm{ZnO} / \mathrm{Al}_{2} \mathrm{O}_{3}-\mathrm{OA}$ Catalysts}

$\mathrm{Ni}$ based catalysts are active in various hydrocarbon reforming $[39,40]$ and glycerol hydrogenolysis processes $[57,58]$ and $\mathrm{Ni}$ is less costly compared to some precious hydrogenation metals such as $\mathrm{Pt}, \mathrm{Pd}$ and $\mathrm{Ru}$. Since the $\mathrm{Cu} / \mathrm{ZnO} / \mathrm{Al}_{2} \mathrm{O}_{3}-\mathrm{OA}$ catalyst is more active and selective to 1,2-PD in the glycerol hydrogenolysis process than $\mathrm{Cu} / \mathrm{ZnO} / \mathrm{Al}_{2} \mathrm{O}_{3}-\mathrm{Na}$, Ni was added to $\mathrm{Cu} / \mathrm{ZnO} / \mathrm{Al}_{2} \mathrm{O}_{3}-\mathrm{OA}$ to further improve the selectivity to 1,2-PD. The $\mathrm{Ni} / \mathrm{Cu} / \mathrm{ZnO} / \mathrm{Al}_{2} \mathrm{O}_{3}-\mathrm{OA}$ catalysts with three different molar contents of $\mathrm{Ni}(1 \%, 3 \%$ and $5 \%)$ were used to investigate the promoting effect of $\mathrm{Ni}$ on the catalytic activity. The products distributions were listed in Table 4, the glycerol conversion, 1,2-PD selectivity, other by-products yields over the reaction time are illustrated in Figure 9. The space-time yields were provided from Tables S5-S7 in the Supplementary Material. From Table 4 and Figure 9a, it can be seen that as $\mathrm{Ni}$ content increased from $0 \%$ to $5 \%$, the glycerol conversion dropped over the reaction time and the final glycerol conversion decreased from $87.1 \%$ to $70.0 \%$. The lower glycerol conversion as more $\mathrm{Ni}$ added is attributed to the loss of $\mathrm{Cu}$ surface area and a reduction of acidity (Tables 1 and 2). The reaction rate of glycerol hydrogenolysis has been reported to be strongly dependent on the $\mathrm{Cu}$ surface area [59,60]. Sato et al. in 2008 reported a mechanism for glycerol dehydration to form acetol catalyzed by a $\mathrm{Cu}$ surface [61]. More experimental evidence will be shown later that $\mathrm{Cu}$ is the primary active site for glycerol dehydration in this reaction system. Since the addition of Ni reduces the number of strong acidic sites (Figure 2, Table 1), a slower reaction rate for the acid catalyzed glycerol dehydration is expected. Therefore, the glycerol conversion was lower with added Ni. Thus, the reaction rate of glycerol dehydration can be affected by two factors, namely the strong acidic sites and $\mathrm{Cu}$ surface area.

Table 4. Products distribution for glycerol hydrogenolysis with in situ $\mathrm{H}_{2}$ from methanol steam reforming over $\mathrm{Cu} / \mathrm{ZnO} / \mathrm{Al}_{2} \mathrm{O}_{3}-\mathrm{OA}$ catalysts with different $\mathrm{Ni}$ loading ${ }^{1}$.

\begin{tabular}{cccccccc}
\hline Ni Molar Content & $\begin{array}{c}\text { Glycerol } \\
\text { Conversion }\end{array}$ & $\begin{array}{c}\text { 1,2-PD } \\
\text { Selectivity }\end{array}$ & $\begin{array}{c}\text { 1,2-PD } \\
\text { Yield }\end{array}$ & $\begin{array}{c}\text { Acetol } \\
\text { Yield }\end{array}$ & $\begin{array}{c}\text { EG } \\
\text { Yield }\end{array}$ & $\begin{array}{c}\text { Propanol } \\
\text { Yield }\end{array}$ & $\begin{array}{c}\text { Others } \\
\text { Yield }\end{array}$ \\
\hline $0 \% \mathrm{Ni}^{2}$ & 87.1 & 70.7 & 61.6 & 5.2 & 2.9 & 0.7 & 16.7 \\
$1 \% \mathrm{Ni}^{3}$ & 85.5 & 76.7 & 65.6 & 4.9 & 3.4 & 0.6 & 11.1 \\
$3 \% \mathrm{Ni}^{4}$ & 77.5 & 82.8 & 64.2 & 3.2 & 3.6 & 0.5 & 5.9 \\
$5 \% \mathrm{Ni}^{5}$ & 70.0 & 85.5 & 59.9 & 3.5 & 3.5 & 0.6 & 2.5 \\
$5 \% \mathrm{Ni}^{5,6}$ & 80.8 & 81.2 & 64.8 & 2.5 & 6.8 & 1.1 & 5.6 \\
$5 \% \mathrm{Ni}^{5,7}$ & 87.0 & 82.9 & 72.1 & 1.3 & 7.7 & 1.2 & 4.7 \\
\hline
\end{tabular}

${ }^{1}$ Reaction Conditions: $220{ }^{\circ} \mathrm{C}, 1.5 \mathrm{MPa} \mathrm{N}, 100 \mathrm{~g}$ feedstock mixture, $20 \mathrm{wt} \%$ glycerol, $32.2 \mathrm{wt} \%$ of water and $47.8 \mathrm{wt} \%$ methanol (water/methanol molar ratio = 1.2), $3 \mathrm{~g}$ catalyst, $500 \mathrm{RPM}, 8 \mathrm{~h} ;{ }^{2} \mathrm{Cu} / \mathrm{Zn} / \mathrm{Al}($ molar $)=35 / 35 / 30 ;{ }^{3} \mathrm{Ni} / \mathrm{Cu} / \mathrm{Zn} / \mathrm{Al}$ $($ molar $)=1 / 34.5 / 34.5 / 30 ;{ }^{4} \mathrm{Ni} / \mathrm{Cu} / \mathrm{Zn} / \mathrm{Al}$ (molar) = 3/33.5/33.5/30; ${ }^{5} \mathrm{Ni} / \mathrm{Cu} / \mathrm{Zn} / \mathrm{Al}$ (molar) = 5/32.5/32.5/30; ${ }^{6} 6 \mathrm{~g}$ catalyst; 79 g catalyst. 

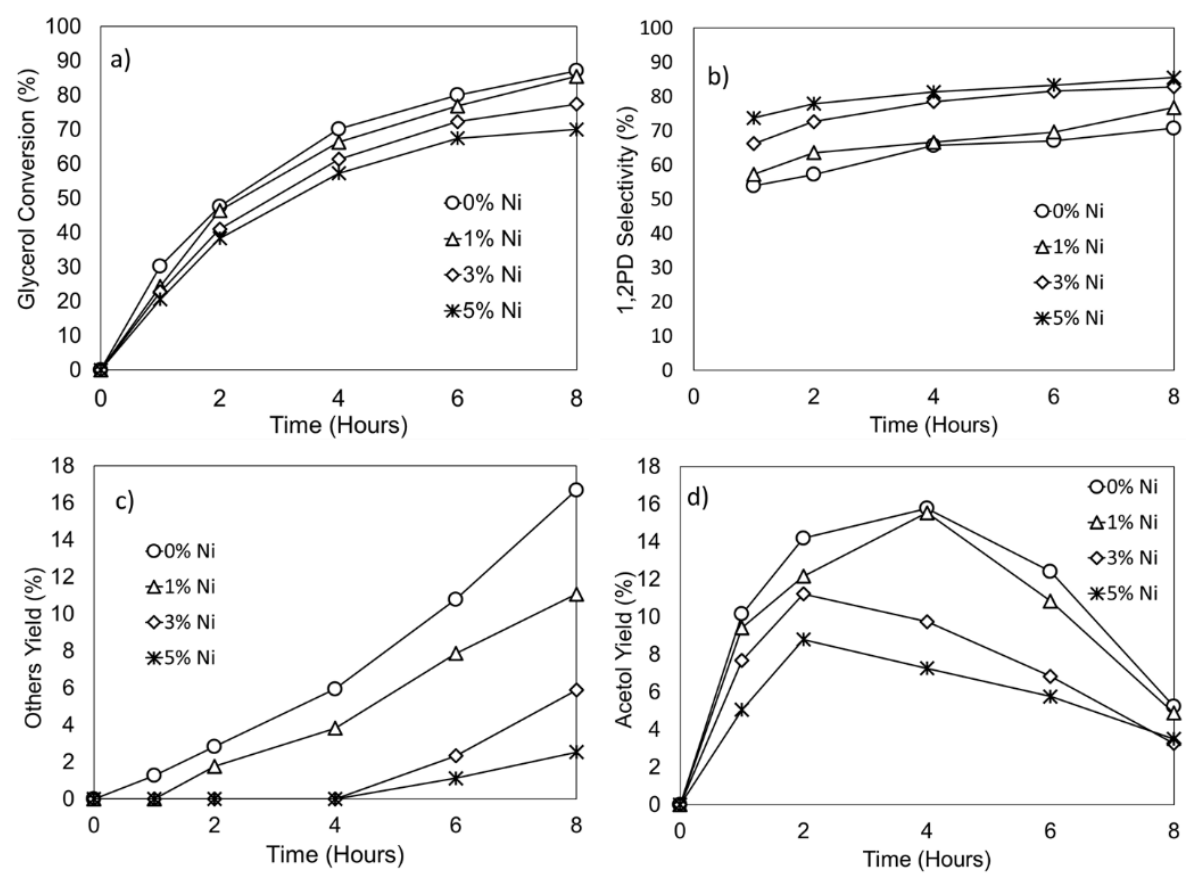

Figure 9. Effect of Ni molar contents on: (a) glycerol conversion; (b) 1,2-propanediol (1,2-PD) selectivity; (c) others yield; (d) acetol yield. Conditions: $220{ }^{\circ} \mathrm{C}, 1.5 \mathrm{MPa} \mathrm{N}, 100 \mathrm{~g}$ feedstock mixture, $20 \mathrm{wt} \%$ glycerol, $32.2 \mathrm{wt} \%$ of water and $47.8 \mathrm{wt} \%$ methanol (water/methanol molar ratio $=1.2$ ), $3 \mathrm{~g}$ catalyst, $500 \mathrm{RPM}$. Catalysts: $\mathrm{Ni} / \mathrm{Cu} / \mathrm{ZnO} / \mathrm{Al}_{2} \mathrm{O}_{3}-\mathrm{OA}$ with different $\mathrm{Ni}$ molar contents. $0 \% \mathrm{Ni}$ : $\mathrm{Cu} / \mathrm{Zn} / \mathrm{Al}$ (molar) = 35/35/30; 1\% Ni: Ni/Cu/Zn/Al (molar) $=1 / 34.5 / 34.5 / 30 ; 3 \% \mathrm{Ni}: \mathrm{Ni} / \mathrm{Cu} / \mathrm{Zn} / \mathrm{Al}$ $($ molar $)=3 / 33.5 / 33.5 / 30 ; 5 \% \mathrm{Ni}: \mathrm{Ni} / \mathrm{Cu} / \mathrm{Zn} / \mathrm{Al}($ molar $)=5 / 32.5 / 32.5 / 30$.

However, it is interesting to note that as $\mathrm{Ni}$ loading is increased from $0 \%$ to $5 \%$, the $1,2-\mathrm{PD}$ selectivity is increased from $70.7 \%$ to $85.5 \%$. In Figure $9 \mathrm{~b}$, it can be seen that the 1,2-PD selectivity is always higher with a higher amount of $\mathrm{Ni}$ loaded over the reaction time. One reason that a higher 1,2-PD selectivity can be obtained as the Ni content is increased to $5 \%$ is because the acetol concentration in the reaction mixture is lower due to the lower dehydration rate suppressing the formation of other by-products caused by the condensation reactions between acetol and alcohols [31]. As illustrated in Figure $9 \mathrm{~d}$, for all types of catalysts, the acetol yields always increase at the early stage of the reaction and then decrease afterward. This is expected as acetol is the intermediate in the reaction system. As more $\mathrm{Ni}$ was added into $\mathrm{Cu} / \mathrm{ZnO} / \mathrm{Al}_{2} \mathrm{O}_{3}-\mathrm{OA}$, the acetol yields over the reaction time were always lower, revealing a lower acetol concentration in the reaction mixture when more $\mathrm{Ni}$ was present in the catalyst. For the $\mathrm{Cu} / \mathrm{ZnO} / \mathrm{Al}_{2} \mathrm{O}_{3}-\mathrm{OA}$ catalyst and the catalyst with $1 \% \mathrm{Ni}$ added, the acetol yields increase and reach their maximum at the fourth hour and then decrease thereafter. When the Ni content is further increased from $3 \%$ to $5 \%$, the acetol concentrations reach the maximum on the second hour, which is earlier than that when lower $\mathrm{Ni}$ is present in the catalyst and then decreases. This trend reveals that at the beginning of the reaction, the major product is acetol when the hydrogen being produced from methanol steam reforming is insufficient to effectively hydrogenate the acetol formed via glycerol dehydration. When the $\mathrm{Ni}$ is added into a $\mathrm{Cu} / \mathrm{ZnO} / \mathrm{Al}_{2} \mathrm{O}_{3}-\mathrm{OA}$ catalyst, the loss of strong acidic sites and $\mathrm{Cu}$ surface area cause a slower glycerol dehydration rate resulting in a lower yield of acetol. This can cause slower rates for the side reactions with acetol to produce lower amounts of undesired by-products as shown in Figure 9c. Ethylene glycol yield at the end of the reaction was also increased from 2.9\% to $3.4 \%$ when $1 \% \mathrm{Ni}$ was added onto the catalyst. When the Ni loading was further increased from $1 \%$ to $5 \%$, the ethylene glycol yield was not significantly changed. The increment of ethylene glycol due to the addition of $\mathrm{Ni}$ is possibly due to the promoting effect of the $\mathrm{Ni}$ on $\mathrm{C}-\mathrm{C}$ cleavage. As shown in Figure 10, both $\mathrm{Cu}$ surface area and the number of strong acidic sites have positive correlations with the glycerol conversion; but they all have negative effects on 1,2-PD selectivity since the higher 
acetol formation rate by glycerol dehydration can cause a higher formation rate of other un-desired by-products when the hydrogen availability is not sufficient for acetol hydrogenation. Therefore, even a slower glycerol conversion rate was obtained using a Ni promoted catalyst, the space-time yield of 1,2-PD was not significantly changed as listed in Table S5, which was found to be $11.0 \mathrm{mmol} / \mathrm{h}$.g-cat, this was very close to the value obtained using a $\mathrm{Cu} / \mathrm{ZnO} / \mathrm{Al}_{2} \mathrm{O}_{3}-\mathrm{OA}$ catalyst in the previous discussion and the reported literature value [30]. It is important to obtain a high 1,2-PD selectivity, since the un-reacted glycerol can be recycled back to the reactor and hence it can reduce the production cost. Otherwise, the high yield of undesired by-products will require separation of other by-products prior to the recycling of glycerol. Even though the glycerol conversion is lower at higher Ni loading, the yield of 1,2-PD is not significantly lowered due to the high 1,2-PD selectivity, as listed in Table 4.
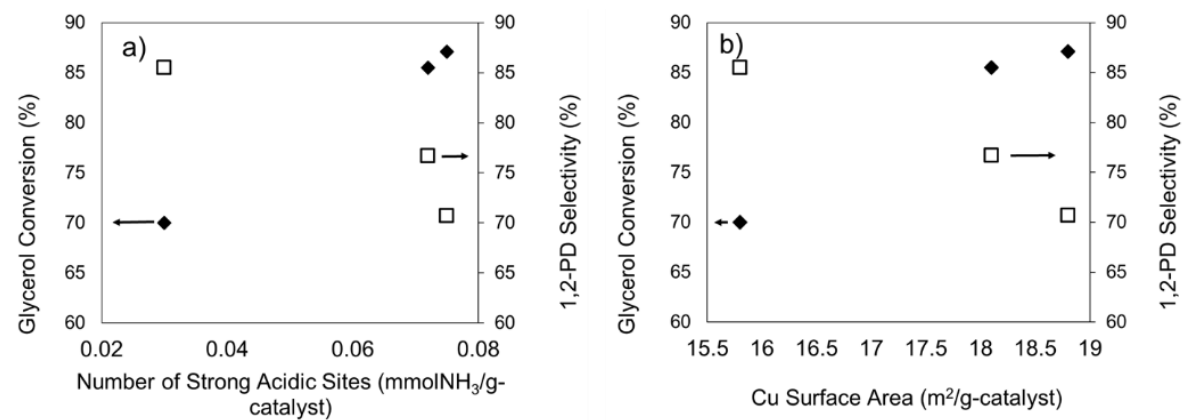

Figure 10. Effect of: (a) Number of strong acidic sites; (b) Cu surface area on glycerol conversion and 1,2-propanediol selectivity. Conditions: $220{ }^{\circ} \mathrm{C}, 1.5 \mathrm{MPa} \mathrm{N}_{2}, 100 \mathrm{~g}$ feedstock mixture, $20 \mathrm{wt} \%$ glycerol, $32.2 \mathrm{wt} \%$ of water and $47.8 \mathrm{wt} \%$ methanol (water/methanol molar ratio $=1.2$ ), $3 \mathrm{~g}$ catalyst, $500 \mathrm{RPM}, 8 \mathrm{~h}$.

The effect of catalyst loading was also investigated by varying the catalyst loading amount from 3 to $9 \mathrm{wt} \%$ with respect to the total weight of feedstock mixture using a $\mathrm{Ni} / \mathrm{Cu} / \mathrm{ZnO} / \mathrm{Al}_{2} \mathrm{O}_{3}-\mathrm{OA}$ catalyst with $5 \% \mathrm{Ni}$ loading as listed in Table 4 . When the catalyst loading was increased from 3 to $9 \mathrm{wt} \%$, the glycerol conversion was increased from $70.0 \%$ to $87.0 \%$ with the 1,2-PD selectivity slightly reduced from $85.5 \%$ to $82.9 \%$. The loss of $1,2-\mathrm{PD}$ selectivity by increasing the catalyst loading is mainly due to the increments of ethylene glycol, propanol and other by-products yields. It is possibly because when the catalyst loading is increased, more active sites can be provided for C-C cleavage, the sequential hydrogenolysis of 1,2-PD and the condensation reactions between acetol and other alcohols resulting in higher yields of ethylene glycol, propanol and other by-products. In addition, when the catalyst loading is higher, more active sites are provided for methanol steam reforming generating more hydrogen, which can also favor the C-C cleavage and 1,2-PD hydrogenolysis to propanol.

As discussed previously, the 1,2-PD selectivity strongly depends on the acetol concentration in the reaction mixture. The un-desired by-products are mainly due to the side reactions of acetol present in the mixture when the hydrogen being produced from methanol steam reforming is not sufficient for the acetol hydrogenation. Therefore, the methanol steam reforming reaction is another key factor improving the 1,2-PD selectivity. The experiments were carried out without taking any sample during the reaction time to investigate the methanol conversion and mole balance of glycerol. In this case, the methanol conversion, glycerol conversion, 1,2-PD selectivity and yields of products were calculated using the equations listed below, where " $\mathrm{i}$ " stands for each product/byproduct formed from glycerol. Table 5 lists the effect of $\mathrm{Ni}$ loading on methanol conversion. To investigate the roles that $\mathrm{Cu}$ and $\mathrm{Ni}$ play in the reaction system, a $\mathrm{Ni} / \mathrm{ZnO} / \mathrm{Al}_{2} \mathrm{O}_{3}-\mathrm{OA}$ catalyst without $\mathrm{Cu}$ present was also used. The mole balances of glycerol were all close to $100 \%$ revealing that glycerol steam reforming did not occur to any significant extent. When $\mathrm{Ni}$ was added to $\mathrm{Cu} / \mathrm{ZnO} / \mathrm{Al}_{2} \mathrm{O}_{3}-\mathrm{OA}$, the methanol conversion was higher. As more hydrogen was produced, acetol could be more effectively hydrogenated resulting in a higher 1,2-PD yield, a lower acetol yield and a lower other by-products yield. It gives a good agreement with the previous discussion that when $\mathrm{Ni}$ was added, the 1,2-PD selectivity was higher, the yield of acetol and the other un-desired by-products were lower (see Figure 9). Therefore, the promoting effect of 
$\mathrm{Ni}$ on methanol steam reforming is the main reason why the addition of $\mathrm{Ni}$ can improve the 1,2-PD selectivity. It is also important to note that when $\mathrm{Ni} / \mathrm{ZnO} / \mathrm{Al}_{2} \mathrm{O}_{3}-\mathrm{OA}$ catalyst was used without $\mathrm{Cu}$ being present, essentially no 1,2-PD was formed, and glycerol conversion was only $4.8 \%$. This suggests that $\mathrm{Cu}$ is the primarily active component in the catalyst for glycerol dehydration. Yfanti et al. [30] have also reported that when $\mathrm{ZnO} / \mathrm{Al}_{2} \mathrm{O}_{3}$ catalyst was used for glycerol hydrogenolysis, no glycerol conversion was obtained indicating $\mathrm{Cu}$ is necessary for dehydration. Thus, it can be deduced that metallic $\mathrm{Ni}$ is inactive for glycerol dehydration and the small amount of glycerol conversion is possibly due to the acidic sites provided by alumina. It can also be known that $\mathrm{ZnO}$ is also inactive for glycerol dehydration from the results in Table 5 and the reported data [30]. However, $\mathrm{ZnO}$ was reported to play an important role on the catalytic activity as it can favor the formation of small active $\mathrm{Cu}$ sites by the $\mathrm{Cu}-\mathrm{ZnO}$ interactions to improve the activity of $\mathrm{Cu}$ catalyst [6]. It is interestingly noted that when $\mathrm{Ni} / \mathrm{ZnO} / \mathrm{Al}_{2} \mathrm{O}_{3}-\mathrm{OA}$ was used, the methanol conversion was $23.3 \%$ which was higher than that using $5 \% \mathrm{Ni} / \mathrm{Cu} / \mathrm{ZnO} / \mathrm{Al}_{2} \mathrm{O}_{3}$-OA catalyst. It was reported that methanol steam reforming reaction did not occur when $\mathrm{ZnO} / \mathrm{Al}_{2} \mathrm{O}_{3}$ was used [30]. Therefore, Ni can improve the catalyst activity for methanol steam reforming to produce more hydrogen for acetol hydrogenation, which is likely one of the main reasons that the addition of $\mathrm{Ni}$ to $\mathrm{Cu} / \mathrm{ZnO} / \mathrm{Al}_{2} \mathrm{O}_{3}-\mathrm{OA}$ catalyst can improve the selectivity of 1,2-PD in this process.

$$
\begin{gathered}
\text { Conversion }_{\text {Glycerol }}=100 \%-\frac{n_{\text {Glycerol, }, \text { in }}-n_{\text {Glycerol, }, f}}{n_{\text {Glycerol, }, \text { in }}} \times 100 \%, \\
\text { Yield }_{i}=\frac{n_{i}}{n_{\text {Glycerol, } i n}} \times 100 \%, \\
\text { Selectivity }_{i}=\frac{\text { Yield }_{i}}{\text { Conversion }_{\text {Glycerol }}} \times 100 \% .
\end{gathered}
$$

Table 5. Promoting effect of $\mathrm{Ni}$ on $\mathrm{Cu} / \mathrm{ZnO} / \mathrm{Al}_{2} \mathrm{O}_{3}-\mathrm{OA}$ activity for glycerol hydrogenolysis and methanol steam reforming ${ }^{1}$.

\begin{tabular}{cccccc}
\hline Catalysts & $\begin{array}{c}\text { Glycerol } \\
\text { Conversion }\end{array}$ & $\begin{array}{c}\text { 1,2-PD } \\
\text { Selectivity }\end{array}$ & $\begin{array}{c}\text { 1,2-PD } \\
\text { Yield }\end{array}$ & $\begin{array}{c}\text { Methanol } \\
\text { Conversion }\end{array}$ & $\begin{array}{c}\text { Mole } \\
\text { Balance }\end{array}$ \\
\hline $\mathrm{Cu} / \mathrm{ZnO} / \mathrm{Al}_{2} \mathrm{O}_{3}-\mathrm{OA}^{2}$ & 100.0 & 77.0 & 77.0 & 17.7 & 96.5 \\
$\mathrm{Ni} / \mathrm{Cu} / \mathrm{ZnO} / \mathrm{Al}_{2} \mathrm{O}_{3}-\mathrm{OA}^{3}$ & 97.4 & 86.0 & 83.8 & 21.6 & 100.4 \\
$\mathrm{Ni} / \mathrm{ZnO} / \mathrm{Al}_{2} \mathrm{O}_{3}-\mathrm{OA}^{4}$ & 4.8 & 0.0 & 0.0 & 23.3 & 94.6 \\
\hline
\end{tabular}

1 Conditions: $220{ }^{\circ} \mathrm{C}, 1.5 \mathrm{MPa} \mathrm{N}_{2}, 100 \mathrm{~g}$ feedstock mixture, $20 \mathrm{wt} \%$ glycerol, $32.2 \mathrm{wt} \%$ of water and $47.8 \mathrm{wt} \%$ methanol (water/methanol molar ratio $=1.2$ ), $3 \mathrm{~g}$ catalyst, $500 \mathrm{RPM}, 24 \mathrm{~h}$. No sample was taken over the reaction time; ${ }^{2} \mathrm{Cu} / \mathrm{Zn} / \mathrm{Al}$ molar ratio $=35 / 35 / 30 ;{ }^{3} \mathrm{Ni} / \mathrm{Cu} / \mathrm{Zn} / \mathrm{Al}$ molar ratio $=5 / 32.5 / 32.5 / 30 ;{ }^{4} \mathrm{Ni} / \mathrm{Zn} / \mathrm{Al}$ molar ratio $=10 / 60 / 30$.

It has been discussed that the major undesired by-products are formed by the condensation reactions between acetol and alcohols; therefore, rapid hydrogenation of acetol to 1,2-PD plays a key role in order to obtain a high 1,2-PD selectivity. To study the promoting effect of $\mathrm{Ni}$ on acetol hydrogenation reaction, experiments using an aqueous acetol solution as the feedstock with a constant hydrogen pressure supplied into the reaction system over the reaction time was carried out using both $\mathrm{Cu} / \mathrm{ZnO} / \mathrm{Al}_{2} \mathrm{O}_{3}-\mathrm{OA}$ catalyst and $\mathrm{Ni} / \mathrm{Cu} / \mathrm{ZnO} / \mathrm{Al}_{2} \mathrm{O}_{3}-\mathrm{OA}$ catalyst. Figure 11 and Table 6 illustrate the effect of $\mathrm{Ni}$ on the acetol hydrogenation reaction. A pseudo-first-order reaction kinetics was applied and the rate constant for acetol hydrogenation reaction was calculated using the following equation, where $k^{\prime}$ is the pseudo-first-order rate at a constant hydrogen pressure:

$$
-\frac{d[\text { acetol }]}{d t}=k[\text { acetol }] P_{H_{2}}=>\ln [\text { acetol }]=-k^{\prime} t+\ln \left[\text { acetol }_{t=0}\right] .
$$



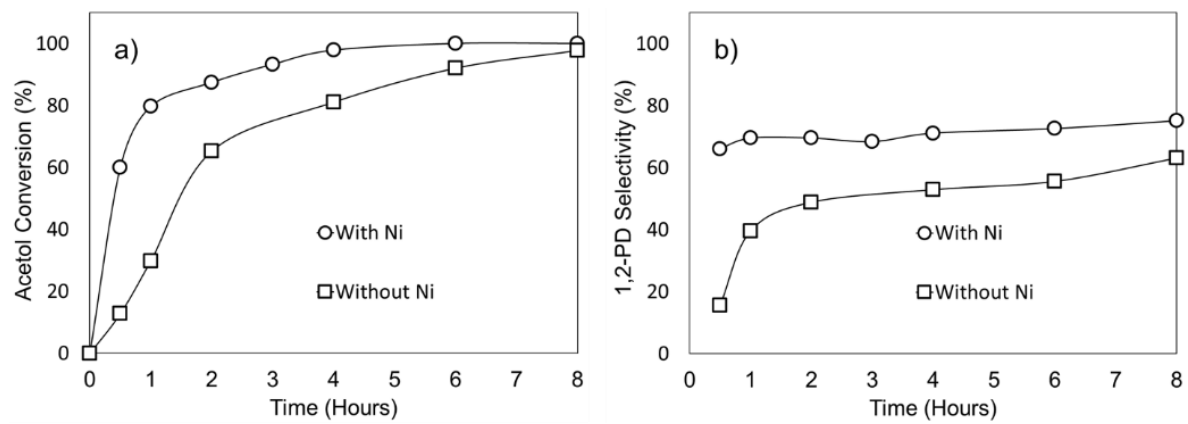

Figure 11. Promoting effect of $\mathrm{Ni}$ on $\mathrm{Cu} / \mathrm{ZnO} / \mathrm{Al}_{2} \mathrm{O}_{3}-\mathrm{OA}$ for acetol hydrogenation: (a) acetol conversion; (b) 1,2-PD selectivity. Conditions: $200{ }^{\circ} \mathrm{C}, 500 \mathrm{RPM}, 100 \mathrm{~g}$ feedstock mixture, $20 \mathrm{wt} \%$ aqueous acetol, $1 \mathrm{~g}$ catalyst, $\mathrm{H}_{2}$ pressure 2.8 PMa. With $\mathrm{Ni}$ : Ni/Cu/Zn/Al (molar) =5/32.5/32.5/30, without Ni: $\mathrm{Cu} / \mathrm{Zn} / \mathrm{Al}=35 / 35 / 30$.

Table 6. Promoting effect of $\mathrm{Ni}$ on $\mathrm{Cu} / \mathrm{ZnO} / \mathrm{Al}_{2} \mathrm{O}_{3}-\mathrm{OA}$ for acetol hydrogenation ${ }^{1}$.

\begin{tabular}{cccccc}
\hline Catalysts & $\begin{array}{c}\text { Acetol } \\
\text { Conversion }\end{array}$ & $\begin{array}{c}\text { 1,2-PD } \\
\text { Selectivity }\end{array}$ & $\begin{array}{c}\text { 1,2-PD } \\
\text { Yield }\end{array}$ & $\begin{array}{c}\text { Others } \\
\text { Yield }\end{array}$ & $\begin{array}{c}\text { Rate Constant } \\
\left(\mathbf{s}^{-\mathbf{1}}\right)\end{array}$ \\
\hline $\mathrm{Cu} / \mathrm{ZnO} / \mathrm{Al}_{2} \mathrm{O}_{3}-\mathrm{OA}^{2}$ & 97.7 & 63.1 & 61.6 & 36.1 & $1.231 \times 10^{-4}$ \\
$5 \% \mathrm{Ni} / \mathrm{Cu} / \mathrm{ZnO} / \mathrm{Al}_{2} \mathrm{O}_{3}-\mathrm{OA}^{3}$ & 100.0 & 75.1 & 75.1 & 24.9 & $2.721 \times 10^{-4}$ \\
\hline
\end{tabular}

${ }^{1}$ Conditions: $200{ }^{\circ} \mathrm{C}, 500 \mathrm{RPM}, 100 \mathrm{~g}$ feedstock mixture, $20 \mathrm{wt} \%$ aqueous acetol, $1 \mathrm{~g}$ catalyst, $\mathrm{H}_{2}$ pressure $2.8 \mathrm{MPa}$, $8 \mathrm{~h}$ reaction time; ${ }^{2} \mathrm{Cu} / \mathrm{Zn} / \mathrm{Al}$ molar ratio $=35 / 35 / 30 ;{ }^{3} \mathrm{Ni} / \mathrm{Cu} / \mathrm{Zn} / \mathrm{Al}$ molar ratio $=5 / 32.5 / 32.5 / 30$.

Using the catalyst with $\mathrm{Ni}$ added, the acetol hydrogenation reaction is significantly faster than that without Ni added (Figure 11a). In fact, the pseudo-first-order rate constant using the Ni catalyst is more than two times larger (Table 6). As the acetol hydrogenation reaction rate is increased, the acetol concentration in the reaction mixture is decreased resulting in slower side reactions caused by acetol to form other by-products. Therefore, the selectivity of 1,2-PD using the $\mathrm{Ni} / \mathrm{Cu} / \mathrm{ZnO} / \mathrm{Al}_{2} \mathrm{O}_{3}-\mathrm{OA}$ catalyst is higher over the reaction time as illustrated in Figure 11b. To investigate the nature of the by-product formation, the chromatogram of the final product sample $(8 \mathrm{~h})$ was compared with the samples obtained for the hydrogenolysis process with methanol steam reforming and the hydrogenolysis process with insufficient external hydrogen added (i.e., 1.4 MPa) as depicted in Figure 12. It can be seen that the retention times of the by-products from the acetol hydrogenation are the same compared with the other two reactions. Hence the by-product formation is due to side reactions of acetol when insufficient hydrogen is provided. Therefore, the selectivity of 1,2-PD is believed to be strongly dependent on the rate of acetol hydrogenation. It is interesting to point out that no ethylene glycol is formed during acetol hydrogenation suggesting that ethylene glycol is formed due to C-C cleavage of glycerol rather than 1,2-PD or acetol. This result is in agreement with a recent mechanistic study of glycerol hydrogenolysis [31]. Since Ni improves the catalytic activity for acetol hydrogenation and also improves the methanol steam reforming to produce more hydrogen for in situ hydrogenation, the addition of $\mathrm{Ni}$ improves the selectivity to 1,2-PD in glycerol hydrogenolysis. 


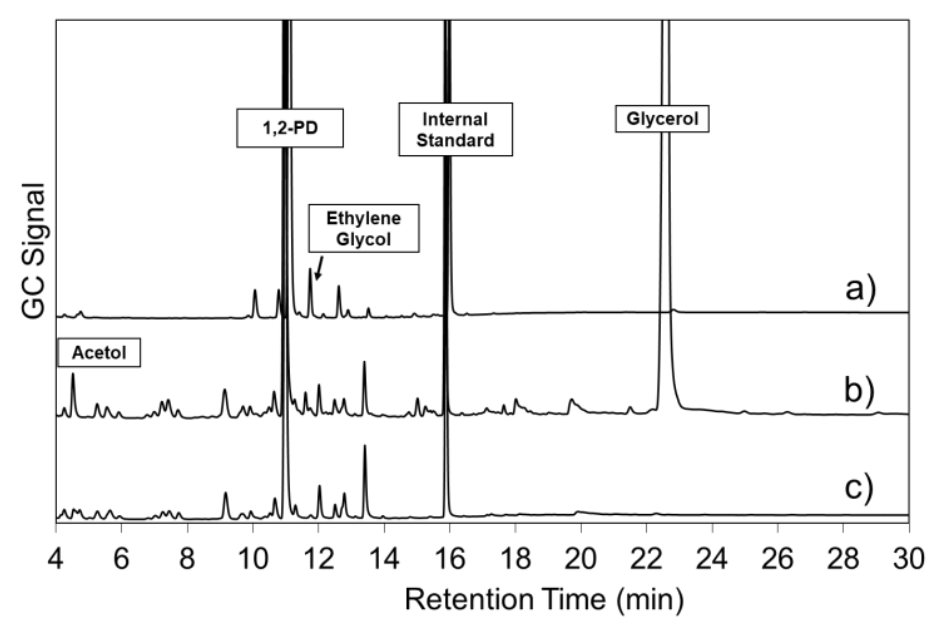

Figure 12. Chromatograms of the final sample of: (a) glycerol hydrogenolysis with methanol steam reforming, (b) glycerol hydrogenolysis with insufficient molecular hydrogen added, (c) acetol hydrogenation. All traces have been displaced for clarity.

\section{Materials and Methods}

\subsection{Materials and Methods for Catalyst Preparation}

Ethanol was purchased from Fisher Scientific Canada (Toronto, ON, Canada) (high-performance liquid chromatography grade). The other chemicals were purchased from Sigma Aldrich Co. Canada (Oakville, ON, Canada) and all the gases were purchased from Praxair Canada Inc. (Mississauga, $\mathrm{ON}$, Canada). The procedures to prepare $\mathrm{Cu} / \mathrm{ZnO} / \mathrm{Al}_{2} \mathrm{O}_{3}$ catalysts via two different precipitation methods, i.e., oxalate gel-co-precipitation and $\mathrm{Na}_{2} \mathrm{CO}_{3}$ co-precipitation have been described in our previous paper [9] referred to as $\mathrm{Cu} / \mathrm{ZnO} / \mathrm{Al}_{2} \mathrm{O}_{3}-\mathrm{OA}$ and $\mathrm{Cu} / \mathrm{ZnO} / \mathrm{Al}_{2} \mathrm{O}_{3}-\mathrm{Na}$ respectively. To prepare the $\mathrm{Cu} / \mathrm{ZnO} / \mathrm{Al}_{2} \mathrm{O}_{3}-\mathrm{Na}$ catalyst, an aqueous mixture of metal nitrates solution was prepared with the designated metal molar ratio under vigorous stirring, the total metal concentration was $0.5 \mathrm{M}$. An aqueous solution of $0.5 \mathrm{M}$ sodium carbonate was added drop-wise into the metal nitrate solution until the $\mathrm{pH}$ of the solution was equal to 9.0. The slurry was then filtered and washed by de-ionized water until the $\mathrm{pH}$ of the filtrate water became 7.0. Then the filtered cake was dried at $110{ }^{\circ} \mathrm{C}$ overnight and calcined under a stationary air environment at $450{ }^{\circ} \mathrm{C}$ for $4 \mathrm{~h}$. $\mathrm{Ni} / \mathrm{Cu} / \mathrm{ZnO} / \mathrm{Al}_{2} \mathrm{O}_{3}$ catalysts were also prepared via oxalate gel-co-precipitation method referred to as $\mathrm{Ni} / \mathrm{Cu} / \mathrm{ZnO} / \mathrm{Al}_{2} \mathrm{O}_{3}-\mathrm{OA}$. To prepare $\mathrm{Cu} / \mathrm{ZnO} / \mathrm{Al}_{2} \mathrm{O}_{3}-\mathrm{OA}$ and $\mathrm{Ni} / \mathrm{Cu} / \mathrm{ZnO} / \mathrm{Al}_{2} \mathrm{O}_{3}-\mathrm{OA}$ catalysts, $20 \%$ excess ethanol solution of $0.5 \mathrm{M}$ oxalic acid (anhydrous, $\geq 97.0 \%$ ) was quickly injected into an ethanol solution mixture of $\mathrm{Ni}\left(\mathrm{NO}_{3}\right)_{2} \cdot 6 \mathrm{H}_{2} \mathrm{O}(\geq 98.5), \mathrm{Cu}\left(\mathrm{NO}_{3}\right)_{2} \cdot 2.5 \mathrm{H}_{2} \mathrm{O}(\geq 98.0 \%), \mathrm{Zn}\left(\mathrm{NO}_{3}\right)_{2} \cdot 6 \mathrm{H}_{2} \mathrm{O}(\geq 98.0 \%)$ and $\mathrm{Al}\left(\mathrm{NO}_{3}\right)_{3} \cdot 9 \mathrm{H}_{2} \mathrm{O}$ $(\geq 98.0 \%)$ with designated metal molar ratio under vigorous stirring, the total metal concentration was $0.5 \mathrm{M}$. The precipitation mixture was then aged at room temperature under stirring for $2 \mathrm{~h}$ and filtered. The filtered cake was then dried in air at $110{ }^{\circ} \mathrm{C}$ for $24 \mathrm{~h}$. The dried particles were powdered and screened via a sieve with $250 \mu \mathrm{m}$ opening and then calcined in stationary air at $150{ }^{\circ} \mathrm{C}$ for $1 \mathrm{~h}, 200{ }^{\circ} \mathrm{C}$ for $1 \mathrm{~h}, 250^{\circ} \mathrm{C}$ for $1 \mathrm{~h}, 300^{\circ} \mathrm{C}$ for $1 \mathrm{~h}$ and $360^{\circ} \mathrm{C}$ for $4 \mathrm{~h} \mathrm{[46].}$

\subsection{Materials and Methods for Catalyst Characterization}

$\mathrm{NH}_{3}$ temperature program desorption (TPD), $\mathrm{N}_{2} \mathrm{O}$ reactive frontal chromatography (RFC) and temperature program reduction (TPR) experiments were carried out using an Altamira AMI-200 instrument (Pittsburgh, PA, USA). For the $\mathrm{NH}_{3}$ TPD experiments, approximately $120 \mathrm{mg}$ of the catalyst was loaded into a $U$ shaped quartz reactor for each test. The catalyst was firstly reduced under a flow of $5 \% \mathrm{H}_{2}$ balanced with argon at a volumetric flow rate of $30 \mathrm{~mL} / \mathrm{min}$ at $300{ }^{\circ} \mathrm{C}$ for $2 \mathrm{~h}$. After reduction, the catalyst was cooled down to $25{ }^{\circ} \mathrm{C}$. Then, 20 pulses of $5 \% \mathrm{NH}_{3}$ balanced with argon were injected into the $U$ tube to saturate all the acidic sites of the catalyst, then the catalyst 
was heated to $1000{ }^{\circ} \mathrm{C}$ at a heating rate of $10{ }^{\circ} \mathrm{C} / \mathrm{min}$. The $\mathrm{NH}_{3}$ desorption profile was determined by analyzing the effluent gas through a thermo conductivity detector (TCD). To carry out the TPR experiments, the catalyst amount was calculated to meet the characteristic $p$ value below $30 \mathrm{~K}$ (see Supplementary Material A2 for calculation of characteristic $p$ value), then the catalyst was firstly heated to $200{ }^{\circ} \mathrm{C}$ and kept at $200{ }^{\circ} \mathrm{C}$ for $60 \mathrm{~min}$ under a flow rate of $30 \mathrm{~mL} / \mathrm{min}$ argon stream to remove all the moisture and other species physically absorbed on the catalyst surface. Then, the catalyst was heated under a $30 \mathrm{~mL} / \mathrm{min}$ flow stream of $5 \% \mathrm{H}_{2}$ balanced with argon at a heating rate of $5^{\circ} \mathrm{C} / \mathrm{min}$ until $800^{\circ} \mathrm{C}$. For the $\mathrm{N}_{2} \mathrm{O}$ RFC experiments, a TPR step was firstly carried out to $300^{\circ} \mathrm{C}$ at a heating rate of $5{ }^{\circ} \mathrm{C} / \mathrm{min}$ to reduce all $\mathrm{Cu}^{2+}$ to $\mathrm{Cu}^{0}$; then the catalyst was cooled down to $60^{\circ} \mathrm{C}$. The surface $\mathrm{Cu}^{0}$ was then oxidized to $\mathrm{Cu}^{1+}$ under a flow of $1 \% \mathrm{~N}_{2} \mathrm{O}$ balanced with argon gas mixture at a flow rate of $30 \mathrm{~mL} / \mathrm{min}$. Then, another TPR program was carried out to $300^{\circ} \mathrm{C}$ at a heating rate of $5{ }^{\circ} \mathrm{C} / \mathrm{min}$ to reduce the entire surface $\mathrm{Cu}^{1+}$ to $\mathrm{Cu}^{0}$. The $\mathrm{H}_{2}$ uptake was then calculated to estimate the copper surface area. Transmission electron microscopy (TEM) was carried out on a FEI Titan 80-300 TEM (Hillsboro, OR, USA) equipped with an aberration corrector for the imaging lens (CEOS). The XRD experiments were carried out on a Bruker D8 Focus model (Madison, WI, USA), with $\mathrm{Cu} k \alpha$ radiation and a wavelength of $1.54 \AA$; the $2 \theta$ angle was $15^{\circ}-55^{\circ}$ with a ramp of $0.02^{\circ}$ per minute. The TGA profiles were obtained on a TA Instrument, SDT Q600 (New Castle, DE, USA). Approximately 10-15 mg catalyst sample was used for each test, the experiments were conducted under a continuous air flow $(40 \mathrm{~mL} / \mathrm{min})$, with a temperature range of $30-600{ }^{\circ} \mathrm{C}$ at a heating rate of $5{ }^{\circ} \mathrm{C} / \mathrm{min}$. The metal content of the catalysts was determined using a Teledyne Leeman Labs high dispersion ICP (Hudson, NH, USA). The DRIFT spectra were collected on a Varian 660 infrared spectrometer (Mulgrave, VIC, Australia) equipped with a DRIFT reaction cell and a liquid nitrogen cooled $\mathrm{HgCdTe}$ (MCT) detector. The catalyst was pre-reduced in situ at $300{ }^{\circ} \mathrm{C}$ for $1 \mathrm{~h}$ in $10 \% \mathrm{H}_{2} / \mathrm{He}$, followed by a purge with He at the same temperature to remove the surface-adsorbed $\mathrm{H}_{2}$. After cooling down to the ambient temperature, $\mathrm{CO}$ was admitted at a desired pressure using a vacuum/adsorption system. The spectra were collected after steady state was reached, and the spectral resolution is $4 \mathrm{~cm}^{-1}$ and the number of scans is 64 .

\subsection{Materials and Methods for Catalysts Activity Test}

The catalytic reactions were carried out in a $300 \mathrm{~mL}$ Parr Instrument 4560 Series mini bench top reactor constructed of hastelloy (Moline, IL, USA). For the glycerol hydrogenolysis reaction with in situ hydrogen produced from methanol steam reforming, $100 \mathrm{~g}$ of feedstock mixture containing $20 \mathrm{wt} \%$ of glycerol, $32.2 \mathrm{wt} \%$ of water and $47.8 \mathrm{wt} \%$ of methanol (water/methanol molar ratio $=1.2$ ) were placed into the reactor. Unless specified, $3 \mathrm{~g}$ of catalyst ( $3 \mathrm{wt} \%$ with respect to the weight of total reactant mixture) was pre-reduced by a hydrogen stream (ultra-high purity) at $300^{\circ} \mathrm{C}$ for $3 \mathrm{~h}$ in a quartz tubular reactor enclosed by a furnace. Then the reduced catalysts were transferred into the reaction mixture rapidly. The reactor was firstly flushed with nitrogen three times and pressurized to a desired pressure at ambient temperature before being heated to the desired temperature. Liquid samples were taken during the reaction time via a sampling valve. For the acetol hydrogenation reaction, $100 \mathrm{~g}$ of aqueous acetol solution containing $20 \mathrm{wt} \%$ of acetol was placed into the reactor, $1 \mathrm{~g}$ of catalyst was reduced and added into the reaction mixture, gaseous hydrogen was used to pressurize the reaction and the hydrogen pressure was kept constant over the reaction time. An Agilent $6890 \mathrm{~N}$ gas chromatograph integrated with a DB-WAX megabore capillary column (Wilminton, DE, USA, $30 \mathrm{~m} \times 0.53 \mathrm{~mm}$ I.D. $\times$ $10 \mu \mathrm{m}$ film thickness) and a flame ionization detector (FID) was used to analyze all the liquid samples. Approximately $120 \mathrm{mg}$ of product sample was added into $1 \mathrm{~mL}$ of 1,4-butanediol n-butanol solution mixture with 1,4-butanediol concentration of $5 \mathrm{~g} / \mathrm{L}$.

\section{Conclusions}

In this study, the promoting effect of $\mathrm{Ni}$ on a $\mathrm{Cu} / \mathrm{ZnO} / \mathrm{Al}_{2} \mathrm{O}_{3}-\mathrm{OA}$ catalyst was investigated in a glycerol hydrogenolysis process to produce 1,2-PD using in situ hydrogen produced via methanol steam reforming. The utilization of methanol in the crude glycerol from a biodiesel production process 
as the hydrogen source will avoid the additional cost for transportation and storage of molecular hydrogen, and the safety risks related to the usage of high pressure hydrogen. The catalyst prepared via oxalate gel-coprecipitation method has a smaller particle size and higher acidity resulting in a higher glycerol conversion and 1,2-PD selectivity. The addition of $\mathrm{Ni}$ onto a $\mathrm{Cu} / \mathrm{ZnO} / \mathrm{Al}_{2} \mathrm{O}_{3}-\mathrm{OA}$ catalyst resulted in a lower glycerol conversion due to the loss of $\mathrm{Cu}$ surface area and strong acidic sites. However, the 1,2-PD selectivity was improved as $\mathrm{Ni}$ was added due to several reasons: first of all the addition of $\mathrm{Ni}$ can improve the catalytic activity on the methanol steam reforming reaction to produce more hydrogen for acetol hydrogenation reducing the undesired by-products formation by some acetol condensation reactions; secondly, the loss of $\mathrm{Cu}$ surface area and strong acidic sites caused by $\mathrm{Ni}$ addition can suppress the glycerol dehydration reaction resulting in a slower rate of acetol yield; the other reason is that $\mathrm{Ni}$ improves the catalytic activity for acetol hydrogenation to 1,2-PD.

Supplementary Materials: The following are available online at http://www.mdpi.com/2073-4344/9/5/412/s1, A1: Calculation of methanol content in crude glycerol, A2: Calculation of $\mathrm{P}$ value, A3: Verification for absence of mass transfer limitations, Table S1: Space Time Yields for glycerol hydrogenolysis with in situ $\mathrm{H}_{2}$ from methanol steam reforming over $\mathrm{Cu} / \mathrm{ZnO} / \mathrm{Al}_{2} \mathrm{O}_{3}-\mathrm{Na}$ catalyst, Tables S2-S4: Space Time Yields for glycerol hydrogenolysis with in situ $\mathrm{H}_{2}$ from methanol steam reforming over $\mathrm{Cu} / \mathrm{ZnO} / \mathrm{Al}_{2} \mathrm{O}_{3}-\mathrm{OA}$ catalysts, Tables S5-S7: Space Time Yields for glycerol hydrogenolysis with in situ $\mathrm{H}_{2}$ from methanol steam reforming over $\mathrm{Ni} / \mathrm{Cu} / \mathrm{ZnO} / \mathrm{Al}_{2} \mathrm{O}_{3}-\mathrm{OA}$ catalysts, Table S8: Space Time Yields for acetol hydrogenation over $\mathrm{Cu} / \mathrm{ZnO} / \mathrm{Al}_{2} \mathrm{O}_{3}-\mathrm{OA}$ catalyst, Table S9: Space Time Yields for acetol hydrogenation over $\mathrm{Ni} / \mathrm{Cu} / \mathrm{ZnO} / \mathrm{Al}_{2} \mathrm{O}_{3}-\mathrm{OA}$ catalyst.

Author Contributions: Conceptualization, Y.L. and F.T.T.N.; methodology, Y.L.; validation, G.L.R. and F.T.T.N.; formal analysis, Y.L. and X.G.; writing-original draft preparation, Y.L.; writing-review and editing, G.L.R. and F.T.T.N.; supervision, G.L.R. and F.T.T.N.; project administration, G.L.R. and F.T.T.N.; funding acquisition, G.L.R. and F.T.T.N.

Acknowledgments: The financial support from Natural Science and Engineer Research Council of Canada (NSERC) Discovery Grant Program is gratefully acknowledged. X. Guo acknowledges the financial support from Shanghai Municipal Education Commission (International Visiting Scholar Program, No. 2014-56) for his research stay at University of Waterloo. We also acknowledge Shandong Dingyu Bio-energy Co. Ltd. for providing the industrial data.

Conflicts of Interest: The authors declare no conflict of interest.

\section{References}

1. Ma, F.; Hanna, M.A. Biodiesel production: A review. Bioresour. Technol. 1999, 70, 1-15. [CrossRef]

2. Pagliaro, M.; Rossi, M. The Future of Glycerol, 2nd ed.; The Royal Society of Chemistry: Cambridge, UK, 2010; pp. $1-170$.

3. Corma, A.; Iborra, S.; Velty, A. Chemical routes for the transformation of biomass into chemicals. Chem. Rev. 2007, 107, 2411-2502. [CrossRef]

4. Chaminand, J.; Djakovitch, L.; Gallezot, P.; Marion, P.; Pinel, C.; Rosier, C. Glycerol hydrogenolysis on heterogeneous catalysts. Green Chem. 2004, 6, 359-361. [CrossRef]

5. Dasari, M.A.; Kiatsimkul, P.; Sutterlin, W.R.; Suppes, G.J. Low-pressure hydrogenolysis of glycerol to propylene glycol. Appl. Catal. A 2005, 281, 225-231. [CrossRef]

6. Wang, S.; Liu, H. Selective hydrogenolysis of glycerol to propylene glycol on Cu-ZnO catalysts. Catal. Lett. 2007, 117, 62-67. [CrossRef]

7. Xia, S.; Yuan, Z.; Wang, L.; Chen, P.; Hou, Z. Hydrogenolysis of glycerol on bimetallic Pd-Cu/solid-base catalysts prepared via layered double hydroxides precursors. Appl. Catal. A 2011, 403, 173-182. [CrossRef]

8. Xia, S.; Nie, R.; Lu, X.; Wang, L.; Chen, P.; Hou, Z. Hydrogenolysis of glycerol over Cu0.4/Zn5.6-xMgxAl2O8.6 catalysts: The role of basicity and hydrogen spillover. J. Catal. 2012, 296, 1-11. [CrossRef]

9. Liu, Y.; Pasupulety, N.; Gunda, K.; Rempel, G.L.; Ng, F.T.T. Glycerol hydrogenolysis to 1,2-propanediol by $\mathrm{Cu} / \mathrm{ZnO} / \mathrm{Al}_{2} \mathrm{O}_{3}$ catalysts. Top. Catal. 2014, 57, 1454-1462. [CrossRef]

10. Ma, L.; He, D.; Li, Z. Promoting effect of rhenium on catalytic performance of Ru catalysts in hydrogenolysis of glycerol to propanediol. Catal. Commun. 2008, 9, 2489-2495. [CrossRef]

11. Jiang, T.; Zhou, Y.; Liang, S.; Liu, H.; Han, B. Hydrogenolysis of glycerol catalyzed by Ru-Cu bimetallic catalysts supported on clay with the aid of ionic liquids. Green Chem. 2009, 11, 1000-1006. [CrossRef] 
12. Graetz, J. New approaches to hydrogen storage. Chem. Soc. Rev. 2009, 38, 73-82. [CrossRef]

13. D'Hondt, E.; Van de Vyver, S.; Sels, B.F.; Jacobs, P.A. Catalytic glycerol conversion into 1,2-propanediol in absence of added hydrogen. Chem. Commun. 2008, 6011-6012. [CrossRef]

14. Vaidya, P.D.; Rodrigues, A.E. Glycerol reforming for hydrogen production: A review. Chem. Eng. Technol. 2009, 32, 1463-1469. [CrossRef]

15. Wen, G.; Xu, Y.; Ma, H.; Xu, Z.; Tian, Z. Production of hydrogen by aqueous-phase reforming of glycerol. Int. J. Hydrogen Energy 2008, 33, 6657-6666. [CrossRef]

16. Barbelli, M.L.; Santori, G.F.; Nichio, N.N. Aqueous phase hydrogenolysis of glycerol to bio-propylene glycol over Pt-Sn catalysts. Bioresour. Technol. 2012, 111, 500-503. [CrossRef]

17. Roy, D.; Subramaniam, B.; Chaudhari, R.V. Aqueous phase hydrogenolysis of glycerol to 1,2-propanediol without external hydrogen addition. Catal. Today 2010, 156, 31-37. [CrossRef]

18. Pendem, C.; Gupta, P.; Chaudhary, N.; Singh, S.; Kumar, J.; Sasaki, T.; Datta, A.; Bal, R. Aqueous phase reforming of glycerol to 1,2-propanediol over Pt-nanoparticles supported on hydrotalcite in the absence of hydrogen. Green Chem. 2012, 14, 3107-3113. [CrossRef]

19. Musolino, M.G.; Scarpino, L.A.; Mauriello, F.; Pietropaolo, R. Selective transfer hydrogenolysis of glycerol promoted by palladium catalysts in absence of hydrogen. Green Chem. 2009, 11, 1511-1513. [CrossRef]

20. Musolino, M.G.; Scarpino, L.A.; Mauriello, F.; Pietropaolo, R. Glycerol hydrogenolysis promoted by supported palladium catalysts. ChemSusChem 2011, 4, 1143-1150. [CrossRef] [PubMed]

21. Gandarias, I.; Arias, P.L.; Requies, J.; El Doukkali, M.; Güemez, M.B. Liquid-phase glycerol hydrogenolysis to 1,2-propanediol under nitrogen pressure using 2-propanol as hydrogen source. J. Catal. 2011, 282, 237-247. [CrossRef]

22. Gandarias, I.; Arias, P.L.; Fernández, S.G.; Requies, J.; El Doukkali, M.; Güemez, M.B. Hydrogenolysis through catalytic transfer hydrogenation: Glycerol conversion to 1,2-propanediol. Catal. Today 2012, 195, $22-31$. [CrossRef]

23. Gandarias, I.; Requies, J.; Arias, P.L.; Armbruster, U.; Martin, A. Liquid-phase glycerol hydrogenolysis by formic acid over $\mathrm{Ni}-\mathrm{Cu} / \mathrm{Al}_{2} \mathrm{O}_{3}$ catalysts. J. Catal. 2012, 290, 79-89. [CrossRef]

24. Gandarias, I.; Fernández, S.G.; El Doukkali, M.; Requies, J.; Arias, P.L. Physicochemical study of glycerol hydrogenolysis over a Ni-Cu/ $\mathrm{Al}_{2} \mathrm{O}_{3}$ catalyst using formic acid as the hydrogen source. Top. Catal. 2013, 56, 995-1007. [CrossRef]

25. Liu, Y. Catalytic Glycerol Hydrogenolysis to Produce 1,2-Propanediol with Molecular Hydrogen and in situ Hydrogen Produced from Steam Reforming. Ph.D. Thesis, University of Waterloo, Waterloo, ON, Canada, 2014.

26. Liu, Y.; Ng, F.T.T.; Rempel, G.L. Glycerol hydrogenolysis to 1,2-propanediol with in situ hydrogen produced from methanol steam reforming. In Advances in Chemistry of Energy \& Fuels, 250th ed.; American Chemical Society National Meeting \& Exposition, Boston, MA, USA, 19 August 2015; American Chemical Society: Washington, DC, USA, 2015; ENFL356.

27. Gaurav, A.; Leite, M.L.; Ng, F.T.T.; Rempel, G.L. Transesterification of triglyceride to fatty acid alkyl esters (biodiesel): Comparison of utility requirements and capital costs between reaction separation and catalytic distillation configurations. Energy Fuels 2013, 27, 6847-6857. [CrossRef]

28. De Sousa Maia, A.C.; e Silva, I.S.; Stragevitch, L. Liquid-liquid equilibrium of methyl esters of fatty acid/methanol/glycerol and fatty acid ethyl esters/ethanol/glycerol: A case study for biodiesel application. Int. J. Chem. Eng. Appl. 2013, 4, 285-289. [CrossRef]

29. Vasiliadou, E.S.; Yfanti, V.-L.; Lemonidou, A.A. One-pot tandem processing of glycerol stream to 1,2-propanediol with methanol reforming as hydrogen donor reaction. Appl. Catal. B 2015, 163, 258-266. [CrossRef]

30. Yfanti, V.-L.; Vasiliadou, E.S.; Lemonidou, A.A. Glycerol hydro-deoxygenation aided by in situ $\mathrm{H}_{2}$ generation via methanol aqueous phase reforming over a $\mathrm{Cu}-\mathrm{ZnO}-\mathrm{Al}_{2} \mathrm{O}_{3}$ catalyst. Catal. Sci. Technol. 2016, 6, 5415-5426. [CrossRef]

31. Yfanti, V.-L.; Lemonidou, A.A. Mechanistic study of liquid phase glycerol hydrodeoxygenation with in-situ generated hydrogen. J. Catal. 2018, 368, 98-111. [CrossRef]

32. Yfanti, V.-L.; Ipsakis, D.; Lemonidou, A.A. Kinetic study of liquid phase glycerol hydrodeoxygenation under inert conditions over a Cu-based catalyst. React. Chem. Eng. 2018, 3, 559-571. [CrossRef]

33. Yfanti, V.-L.; Ipsakis, D.; Lemonidou, A.A. Kinetic model of glycerol hydrodeoxygenation under inert conditions over copper catalyst. Mater. Today Proc. 2018, 5, 27482-27490. [CrossRef] 
34. Chiu, C.; Tekeei, A.; Ronco, J.M.; Banks, M.; Suppes, G.J. Reducing byproduct formation during conversion of glycerol to propylene glycol. Ind. Eng. Chem. Res. 2008, 47, 6878-6884. [CrossRef]

35. Van Ryneveld, E.; Mahomed, A.S.; van Heerden, P.S.; Friedrich, H.B. Direct hydrogenolysis of highly concentrated glycerol solutions over supported Ru, Pd and Pt catalyst systems. Catal. Lett. 2011, 141, 958-967. [CrossRef]

36. Bienholz, A.; Schwab, F.; Claus, P. Hydrogenolysis of glycerol over a highly active CuO/ZnO catalyst prepared by an oxalate gel method: Influence of solvent and reaction temperature on catalyst deactivation. Green Chem. 2010, 12, 290-295. [CrossRef]

37. Shen, J.; Song, C. Influence of preparation method on performance of $\mathrm{Cu} / \mathrm{Zn}$-based catalysts for low-temperature steam reforming and oxidative steam reforming of methanol for $\mathrm{H}_{2}$ production for fuel cells. Catal. Today 2002, 77, 89-98. [CrossRef]

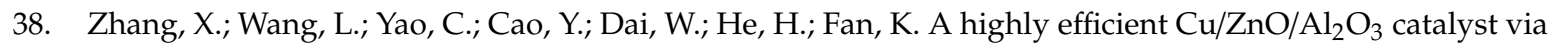
gel-coprecipitation of oxalate precursors for low-temperature steam reforming of methanol. Catal. Lett. 2005, 102, 183-190. [CrossRef]

39. Iwasa, N.; Masuda, S.; Takezawa, N. Steam reforming of methanol over Ni, Co, Pd and Pt supported on ZnO. React. Kinet. Catal. Lett. 1995, 55, 349-353. [CrossRef]

40. Qi, C.; Amphlett, J.C.; Peppley, B.A. Methanol steam reforming over NiAl and Ni (M) Al layered double hydroxides $(\mathrm{M}=\mathrm{Au}, \mathrm{Rh}, \mathrm{Ir})$ derived catalysts. Catal. Lett. 2005, 104, 57-62. [CrossRef]

41. Jiang, T.; Huai, Q.; Geng, T.; Ying, W.; Xiao, T.; Cao, F. Catalytic performance of Pd-Ni bimetallic catalyst for glycerol hydrogenolysis. Biomass Bioenergy 2015, 78, 71-79. [CrossRef]

42. Banu, M.; Sivasanker, S.; Sankaranarayanan, T.M.; Venuvanalingam, P. Hydrogenolysis of sorbitol over Ni and Pt loaded on NaY. Catal. Commun. 2011, 12, 673-677. [CrossRef]

43. Pompeo, F.; Santori, G.F.; Nichio, N.N. Hydrogen production by glycerol steam reforming with Pt/SiO 2 and $\mathrm{Ni} / \mathrm{SiO}_{2}$ catalysts. Catal. Today 2011, 172, 183-188. [CrossRef]

44. Damyanova, S.; Spojakina, A.; Jiratova, K. Effect of mixed titania-alumina supports on the phase composition of $\mathrm{NiMo} / \mathrm{TiO}_{2}-\mathrm{Al}_{2} \mathrm{O}_{3}$ catalysts. Appl. Catal. A 1995, 125, 257-269. [CrossRef]

45. Niemantsverdriet, J.W. Spectroscopy in Catalysis: An Introduction, Third, Completely Revised and Enlarged, 3rd ed.; Wiley-VCH Verlag GmbH \& Co. KGaA: Weinheim, Germany, 2007; pp. 13-21.

46. Sun, Q.; Zhang, Y.; Chen, H.; Deng, J.; Wu, D.; Chen, S. A novel process for the preparation of $\mathrm{Cu} / \mathrm{ZnO}$ and $\mathrm{Cu} / \mathrm{ZnO} / \mathrm{Al}_{2} \mathrm{O}_{3}$ ultrafine catalyst: Structure, surface properties, and activity for methanol synthesis from $\mathrm{CO}_{2}+\mathrm{H}_{2}$. J. Catal. 1997, 167, 92-105. [CrossRef]

47. Wang, L.; Liu, Q.; Chen, M.; Liu, Y.; Cao, Y.; Fan, K.N. Structural evolution and catalytic properties of nanostructured $\mathrm{Cu} / \mathrm{ZrO}_{2}$ catalysts prepared by oxalate gel-coprecipitation technique. J. Phys. Chem. C 2007, 111, 16549-16557. [CrossRef]

48. Hadjiivanov, K.; Venkov, T.; Knözinger, H. FTIR spectroscopic study of CO adsorption on $\mathrm{Cu} / \mathrm{SiO}_{2}$ : Formation of new types of copper carbonyls. Catal. Lett. 2001, 75, 55-59. [CrossRef]

49. Li, D.; Sakai, S.; Nakagawa, Y.; Tomishige, K. FTIR study of CO adsorption on Rh/MgO modified with Co, $\mathrm{Ni}, \mathrm{Fe}$, or $\mathrm{CeO}_{2}$ for the catalytic partial oxidation of methane. Phys. Chem. Chem. Phys. 2012, 14, 9204-9213. [CrossRef]

50. Poncelet, G.; Centeno, M.A.; Molina, R. Characterization of reduced $\alpha$-alumina-supported nickel catalysts by spectroscopic and chemisorption measurements. Appl. Catal. A 2005, 288, 232-242. [CrossRef]

51. Garland, C.W.; Lord, R.C.; Troiano, P.F. Infrared spectrum of carbon monoxide chemisorbed on evaporated nickel films. J. Phys. Chem. 1965, 69, 1195-1203. [CrossRef]

52. Xi, J.; Wang, Z.; Lu, G. Improvement of $\mathrm{Cu} / \mathrm{Zn}$-based catalysts by nickel additive in methanol decomposition. Appl. Catal. A 2002, 225, 77-86. [CrossRef]

53. Cheng, W. Reaction and XRD studies on $\mathrm{Cu}$ based methanol decomposition catalysts: Role of constituents and development of high-activity multicomponent catalysts. Appl. Catal. A 1995, 130, 13-30. [CrossRef]

54. Wu, H.; Chung, S. Kinetics of hydrogen production of methanol reformation using $\mathrm{Cu} / \mathrm{ZnO} / \mathrm{Al}_{2} \mathrm{O}_{3}$ catalyst. J. Comb. Chem. 2007, 9, 990-997. [CrossRef]

55. Meher, L.C.; Gopinath, R.; Naik, S.N.; Dalai, A.K. Catalytic hydrogenolysis of glycerol to propylene glycol over mixed oxides derived from a hydrotalcite-type precursor. Ind. Eng. Chem. Res. 2009, 48, 1840-1846. [CrossRef] 
56. Wang, S.; Zhang, Y.; Liu, H. Selective hydrogenolysis of glycerol to propylene glycol on Cu-ZnO composite catalysts: Structural requirements and reaction mechanism. Chem. Asian J. 2010, 5, 1100-1111. [CrossRef]

57. Jiménez-Morales, I.; Vila, F.; Mariscal, R.; Jiménez-López, A. Hydrogenolysis of glycerol to obtain 1,2-propanediol on Ce-promoted Ni/SBA-15 catalysts. Appl. Catal. B 2012, 117-118, 253-259. [CrossRef]

58. Yu, W.; Zhao, J.; Ma, H.; Miao, H.; Song, Q.; Xu, J. Aqueous hydrogenolysis of glycerol over Ni-Ce/AC catalyst: Promoting effect of Ce on catalytic performance. Appl. Catal. A 2010, 383, 73-78. [CrossRef]

59. Vasiliadou, E.S.; Lemonidou, A.A. Investigating the performance and deactivation behaviour of silica-supported copper catalysts in glycerol hydrogenolysis. Appl. Catal. A 2011, 396, 177-185. [CrossRef]

60. Vasiliadou, E.S.; Eggenhuisen, T.M.; Munnik, P.; de Jongh, P.E.; de Jong, K.P.; Lemonidou, A.A. Synthesis and performance of highly dispersed $\mathrm{Cu} / \mathrm{SiO}_{2}$ catalysts for the hydrogenolysis of glycerol. Appl. Catal. B 2014, 145, 108-119. [CrossRef]

61. Sato, S.; Akiyama, M.; Takahashi, R.; Hara, T.; Inui, K.; Yokota, M. Vapor-phase reaction of polyols over copper catalysts. Appl. Catal. A 2008, 347, 186-191. [CrossRef]

(C) 2019 by the authors. Licensee MDPI, Basel, Switzerland. This article is an open access article distributed under the terms and conditions of the Creative Commons Attribution (CC BY) license (http://creativecommons.org/licenses/by/4.0/). 